\title{
ENTRE LA REGENERACIÓN EDUCATIVA Y LAS POLÉMICAS LITERARIAS: LA "SÁTIRA GRAMATICAL” Y LA FIGURA DEL PROFESOR DE LATINIDAD EN ESCRITORES Y "HOMBRES DE LETRAS” DEL SIGLO XVIII ESPAÑOL
}

\author{
BETWEEN EDUCATIONAL REGENERATION \\ AND LITERARY POLEMICS: THE "SÁTIRA GRAMATICAL" \\ AND THE FIGURE OF THE LATIN PROFESSOR IN \\ WRITERS AND "MEN OF LETTERS” IN SPAIN 18TH CENTURY
}

\author{
JAVIER EsPino MARTíN \\ Universidad Nacional Autónoma de México \\ Instituto de Investigaciones Filológicas \\ condotiericda@yahoo.es
}

\begin{abstract}
RESUMEN: En el siguiente artículo se analiza la formación de la "sátira gramatical”, de tipo carnavalesco, en su aplicación a la figura literaria del profesor de latinidad dentro del entorno de las polémicas literarias del siglo XVIII español. En la primera parte del estudio definimos el concepto y presentamos un panorama de autores representativos a lo largo de la historia de la literatura que han empleado en sus obras esta variedad del género satírico. En la segunda parte estudiamos detalladamente la aplicación literaria de la "sátira gramatical" en la manera de representar la figura literaria del profesor de latín, cuyo empleo deja de manifiesto las polémicas literarias de "eruditos" y "hombres de letras" en cinco obras concretas del siglo xviıI español.

Palabras clave: sátira gramatical; modalidad de género literario; sátira romana; sátira carnavalesca; siglo Xvıı español.
\end{abstract}

Abstract: In the following article an analysis is made of the emergence of the carnivalesque "grammatical satire", as exemplified in the literary figure of the Latin teacher in the context of the literary polemics of 18th century Spain. In the first part of the study, we define the concept and present an overview of representative authors who, throughout the history of literature, have used this variety of satirical genre in their works. In the second part, we study in detail the way in which "grammatical satire" represents the specific literary figure of the Latin teacher, in an effort to demonstrate how this 
figure highlights the literary polemics of "scholars" and "men of letters" in five works from 18 th century Spain.

Keywords: Grammatical satire; kind of literary genre; roman satire; carnivalesque satire; 18 th century Spain.

Recepción: 18 de enero de 2016; aceptación: 26 de mayo de 2016.

\section{LA SÁTIRA GRAMATICAL DEL ENSEÑANTE DE LATINIDAD EN SU CONTEXTO HISTÓRICO-LITERARIO*}

En su ensayo titulado Du pedantisme, Michel de Montaigne nos relata cómo durante su infancia le producía frecuente enojo ver aparecer en las comedias italianas a un ridículo preceptor. El mundo de la enseñanza ha dado lugar, durante siglos, a manifestaciones festivas, satíricas, incluso carnavalescas, que resultan, en su conjunto, un interesante documento histórico y literario. Así las cosas, nuestro propósito en este trabajo es mostrar, mediante una selección de varias obras de autores españoles del siglo XVIII, la aplicación del análisis de una modalidad específica del género de la sátira, que podemos denominar "sátira gramatical", en la figura literaria del enseñante de latín y el método que éste emplea en su didáctica de la lengua. Según esto, el principal propósito de la "sátira gramatical" es el de exponer una crítica literaria contra la nociva didáctica de la lengua latina a través de la figura del "pedante"1, o del maestro

* Este artículo se inscribe dentro del marco del proyecto PAPIIT, clave IA400915, con título "Recepción clásica y modernidad. Autores de la Antigüedad clásica en la configuración del pensamiento ilustrado y romántico", cuyo investigador responsable es Javier Espino Martín. Agradezco al proyecto que se nos brinde la posibilidad de publicar el presente trabajo. También agradecemos profundamente la revisión que este artículo ha tenido por parte del profesor García Jurado.

${ }^{1}$ No hemos de olvidar que en torno a la figura del "pedante" nos encontramos con una abundante literatura en Italia, especialmente entre los siglos XV-Xvi, que tiene su origen en la comedia Il Pedante de Francesco Belo, impresa en Roma en 1538. A partir de esta comedia se escribirá toda una serie de obras literarias acerca de esta figura caricaturesca que hunde sus raíces en los "tipos" de la Commedia dell'arte. Estas obras culminarán en la figura literaria de Fidenzio Glottocristo Ludimagistro, creado por Camilo Scrofa y que protagoniza los Cánticos di Fidenzio, los cuales darán lugar "a la divertida y rica literatura pedantesca o fidenciana” (UGo DéTtore 2006, p. 6795). 
ignorante, el comúnmente llamado "dómine". Por un lado, la "sátira gramatical" posee un carácter moralizante en la crítica de actitudes y vicios de este tipo de educadores que quedan plasmados en una didáctica nociva. Por otro lado, comparte rasgos del género carnavalesco y burlesco, que analizó profusamente Mijail Bajtin en su célebre estudio La cultura popular en la Edad Media y el Renacimiento. El contexto de François Rabelais. La censura a los malos enseñantes se muestra a través de una visión caricaturesca, muy propia de la risa festiva y paródica (Bajtin 1998, pp. 16-17), de su fisonomía y de su personalidad a la vez que de sus adoctrinamientos. En ellos aplica lo que Pérez Lasheras califica como "técnica reductiva",

basada en una serie de recursos que «destruyen la unidad que existe entre la realidad y sus atributos tal como los conocemos, y los reemplazan con cualidades reductivas, paródicas y a veces irónicas» en un afán de potenciar la comicidad del personaje en relación con su entorno también caricaturizado (1994, p. 126).

La "sátira gramatical" acerca del preceptor de latinidad se encuentra dentro de obras de un gran número de escritores desde la Antigüedad clásica hasta la actualidad. Así, por ejemplo, ya en la literatura griega clásica, autores como Aristófanes, Menandro o Sexto Empírico, criticaban la figura del gramático ${ }^{2}$, pero especialmente será en la latina donde más hallemos esta crítica, en las obras de autores como Plauto, Horacio, Persio, Juvenal o Marcial, entre otros ${ }^{3}$. Aproximadamente, a partir del siglo $\mathrm{xv}$, la ironía sarcástica (pars destruens) junto con lo utópico (pars

${ }^{2}$ En la literatura griega nos encontramos con la burla de Aristófanes contra Sócrates en las Nubes, que aparece representado, precisamente, como maestro de una escuela de jóvenes a los que corrompe con sus enseñanzas e insensateces basadas en el argumento "injusto"; o también con las comedias de Menandro tituladas El escudo y El doble burlador, donde aparecen en tono cómico las figuras de dos pedagogos, Daos y Lidos. Solamente a partir de la obra del filósofo griego escéptico Sexto Empírico, Adversus grammaticos, es cuando se empieza a perfilar sustancialmente la figura del gramático como tema de sátira. En esta obra se va dejando bien definida la figura "ruda", "inepta", "pedante" e "irrisoria" del gramático, que tanto influirá en las épocas sucesivas (BERGUA CAVERo 1997, p. 10).

3 Aparte de las referencias satíricas particulares a los enseñantes de cada autor latino, cabe resaltar el estudio panorámico sobre ellos de J. LópEz DE SANTAMARía 1994. 
construens $)^{4}$ serán de los recursos más empleados como crítica pedagógica a caballo entre el espacio literario y el educativo. Gracias a ello, desde el Renacimiento se empezará a configurar verdaderamente el concepto de "sátira gramatical" que, por un lado, ha de centrarse en la burla del gramático escolástico medieval $^{5}$ como enseñante severo y adusto y, por otro, intensificará el análisis denostador que ya se veía esbozado desde la antigua Grecia, como en la citada obra de Sexto Empírico. Por otro lado, en el periodo renacentista, entre los siglos XV y XVI, son notables las referencias satíricas a enseñantes de latinidad escolásticos y medievales en muy variadas manifestaciones literarias $^{6}$, por parte de autores tan relevantes como Rabelais en su Gargantúa y Pantagruel, o Erasmo de Rotterdam, Pontano, Valla, Montaigne y, ya en el siglo siguiente, Molière. Tampoco España se quedó atrás en escritores que hacen de la "sátira gramatical" el caballo de batalla con que combatir un sistema educativo ya deteriorado. Así, por ejemplo, la utilizaron autores de la talla de Nebrija, Cervantes, Luis Vives, Cristóbal de Villalón o Saavedra Fajardo ${ }^{7}$. La semblanza satírica que se da en el periodo barroco busca la negatividad y el afán destructivo y carnavalesco de la figura del profesor de latinidad, como se puede apreciar en el Buscón de Francisco de Quevedo y en la Vida del escudero Marcos Obregón de Vicente Espinel. En estas obras se hiperboliza tanto la pars destruens como la "técnica reductiva".

${ }^{4}$ Con el Humanismo, la Reforma y la Contrarreforma se pone en entredicho los métodos y modelos educativos existentes hasta el momento, y la mejor manera de criticarlos es mediante la pars destruens, burlándose sarcásticamente mediante la sátira de lo existente, o la pars construens, creando un mundo ideal, utópico, en el que se superen y se solucionen los problemas vigentes (Alieghero Manacorda 1987, p. 319).

${ }^{5}$ En cuanto al aspecto económico, social y cultural que afectaba la profesión del gramático, véase Gil Fernández 1980.

${ }^{6}$ De esa variada mescolanza de características, la visión satírica del profesor de latín adquiere las particularidades de un aspecto propio y heterogéneo, si bien dependiente de la sátira. De esta forma, de cada una de las manifestaciones literarias citadas en las que ha ido apareciendo, la visión satírica del enseñante de latinidad ha ido asimilando las peculiaridades propias de los géneros en que se muestra.

${ }^{7}$ Un estudio más detallado de los autores españoles mencionados es el de F. García Jurado \& J. Espino Martín 2009.

8 Un recurso de reducción es el empleo de la máscara satírica, con "recursos básicos como la profusión escénica y lingüística, junto a los tropos metafóricos (principalmente por medio de la comparación y el símil), la antonomasia y la ironía” (Pérez Lasheras 1994, p. 126). El episodio de 
En el siglo XVIII se mantienen la técnica reductiva y la pars destruens, a través de las premisas satíricas carnavalescas, en su vertiente tanto fisiognómica como didáctico-moral ${ }^{9}$. No obstante, si esto es así, debido a la influencia inglesa de la true satire de Joseph Addison (1672-1719) y Richard Steele (1672-1729), se modera y "racionaliza" (Uzcanga 2001, p. 426), por lo que se convierte, más que en un acto de "risa festiva" o "humor grotesco", en, "de acuerdo a la ideología ilustrada, útil al bien común". De este modo, la pars destruens, que se daba prácticamente sola en el Barroco, evoluciona a una pars construens de carácter utópico-social. Por eso mismo, la sátira dieciochesca aligera su carácter más mordaz pero se expande, ya que por beneficio de la formación adecuada de la ciudadanía ocupa ahora "todos los ámbitos de la sociedad" (p. 425). Como veremos en los dos apartados siguientes, la "sátira gramatical" sobre el profesor de latín ofrece dos vertientes:

1) Partiendo de la perspectiva caricaturesca de siglos precedentes (especialmente de la heredera del "barroco licenciado Cabra”, de Quevedo) se presenta al preceptor de latín como un "tipo" más dentro de los personajes grotescos de la sociedad, pero con el propósito no tan sólo de "reírse de él", sino de ofrecer una "crítica constructiva" contra la "perniciosa e ignorante" forma de enseñar el latín de estos dómines, que con su deformada didáctica perjudican "el bien común" y siguen manteniendo la sociedad española estancada en una obsoleta y anticuada educación barroca, que requiere de una mejoría inminente. Así pues, el carácter paródico y humorístico contra el "dómine" busca intensificar el aspecto negativo de lo que denuncia con

la descripción del licenciado Cabra en el cap. 3 del Buscón ejemplifica la utilización de esta técnica reductiva (véase nuestro análisis sobre la imagen caricaturizada del licenciado Cabra: F. García Jurado \& J. EsPino Martín 2009, pp. 29-35).

9 Uno de los aspectos se percibe en que, mientras la sátira durante los siglos XVI y XVII sirvió para cuestionar los modelos educativos vigentes, como las enseñanzas gramaticales de la escolástica, en el XVıII, también se empezará a usar, debido a los inminentes adelantos tecnológicos y por el mayor peso de las lenguas modernas, para cuestionar el que se aprenda la propia gramática latina. De este modo, a finales del siglo XVII en la querelle des anciens et des modernes ya se empieza a discutir la importancia del latín frente a las lenguas nacionales, las visiones lingüísticas y gramaticales del humanismo y la concepción lógico-racional de Port-Royal. A esta polémica contribuirá de forma activa Jonathan Swift con su obra satírica, Historia de una barrica, seguido de la batalla entre los libros antiguos y modernos (1694-1697). 
el fin de regenerar el propio panorama educativo y social de la monarquía española. Éste será el tipo de sátira que se manifestará, principalmente, en las obras tanto del padre Isla como de Vegas y Quintano.

2) En la segunda mitad del siglo (que se intensificará a partir de la década de los años ochenta), la sátira servirá como principal instrumento ideológico, literario y político en las "llamadas «guerrillas literarias» entre escritores enemistados" (p. 427) que buscan medrar en el sistema burocrático cultural borbónico de Carlos III y Carlos IV. Unas veces, por quitarse de en medio al contrincante, y otras, por envidia, la sátira adquirirá un tono de diatriba y crecerá en mordacidad y sarcasmo contra "hombres de letras" determinados que eran presentados como unos "pedantes" al estilo del petit-maître francés (que es en lo que evoluciona el pedante humanista ${ }^{10}$ ) de saber superficial e impostado. Es el caso del autor anónimo Vera de la Ventosa con Pablo de Olavide, y de Forner con Juan y Tomás de Iriarte.

Por último, debemos advertir que tanto la primera vertiente satírica como la segunda se entremezclan de forma que muchas veces los "dómines" de Isla y Vegas y Quintano aparecen reflejados como pedantes "hombres de letras" dieciochescos, a la vez que, al revés, en Forner o Vera de la Ventosa se empleaban rasgos carnavalescos y caricaturescos propios de la sátira quevedesca.

SÁTIRA Y LATINIDAD EN EL PANORAMA EDUCATIVO DEL SIGLO XVIII ESPAÑOL: EL PROFESOR DE LATÍN DESDE LA PERSPECTIVA CARNAVALESCA Y DIDÁCTICO-MORALIZANTE DEL PADRE ISLA Y DE Vegas y Quintano

La situación de la enseñanza del latín en la España del siglo xviII era caótica, anárquica y desorganizada (igual que refiere Aguilar Piñal 1998, p. 227, para la enseñanza secundaria de este periodo, de "aspecto disforme y caótico"). Desde el siglo XVII, el aprendizaje de la lengua del Lacio era fundamental para acceder a ciertos puestos burocráticos de alto nivel, así como para participar en la vida religiosa y ostentar cargos eclesiásticos. Por

10 La importancia política y cultural de la Francia dieciochesca creará una especie de moda francesa en todos los campos del saber que será la causante de que surja un tipo de enseñante pretencioso y pedante, que adoptará artificiosamente el gusto francés en el aprendizaje del latín, una especie de petit-maître en la enseñanza. 
eso mismo, la enseñanza del latín era básicamente propedéutica y se antojaba como requisito fundamental para un despliegue profesional y laboral en la sociedad tanto del Barroco como de la Ilustración. En los siglos XVII y XVIII el aprendizaje de la lengua de Virgilio quedaba repartido en varios centros educativos ${ }^{11}$, como eran: las Escuelas de Gramática de capitales y poblaciones relevantes de provincia; las Escuelas de Gramática catedralicias; los seminarios religiosos que o bien formaban seglares o bien futuros integrantes del cuerpo eclesiástico; los seminarios de nobles; academias y escuelas de artes y oficios que requirieran la lengua latina por la relevancia de su estructura educativa; y las Facultades de Artes de las universidades.

A toda esta enseñanza institucional se oponía la que ejercían las "escuelas privadas de gramática" o el pupilaje particular en "casas de nobles y ricos hacendados" (Bartolomé Martínez 1993, p. 817), desarrollada por preceptores llamados comúnmente "leccionistas", que se caracterizaban por sus "miserables honorarios" y por su "ridícula educación y enseñanza" (p. 508; fueron especialmente satirizados en el siglo XVII en obras como el citado Buscón, de Quevedo, o El bachiller de Salamanca, de Alain René Lesage). De hecho, tanto en el siglo XVII como en el XVIII, los instructores de humanidades clásicas "no tenían para impartir estas enseñanzas ninguna preparación específica ni menos título alguno acreditativo". Este tipo de profesión se había convertido "en una tarea «de oficio», aprendido como pasantes de otros preceptores experimentados, cuando no se trataba de un seguimiento literal de la organización y métodos escolares como los que habían realizado en su preparación con los jesuitas". De ahí que este tipo de enseñantes ejercieran una especie de "habilidad pedagógica" y "técnicas didácticas" que eran "estrictamente personales" (p. 510), sin libros ni maestros que hubieran configurado una escuela de enseñanza. Lo normal es que hubiesen aprendido la lengua latina en el "oficializado", por decreto real de 1599, Arte de Nebrija, refundido por el jesuita Juan Luis de la Cerda y/o por la miríada de "manualillos", que explicaban y detallaban las partes del Arte. Esta enseñanza, a la que volveremos más adelante, era profundamente barroca, llena de reglas, excepciones y ejemplos, confusa y aparatosa. Si ya de por sí, esta

11 Acerca de la enseñanza preuniversitaria de la latinidad durante el siglo xviII, véase B. Bartolomé Martínez 1993; F. Aguilar Piñal 1988; y O. Negrín Fajardo 2009, pp. 239-244. 
forma de aprendizaje del latín desviaba la futura pedagogía de los dómines, a lo que añadimos el propio carácter "personal" por la que éstos se regían, era muy fácil que su didáctica se acabara enviciando y desviando todavía más. En palabras de Bernabé Bartolomé Martínez,

se trataba de grupos de bachilleres o dómines, de clérigos o capellanes adscritos a una prebenda beneficial que, según los arbitristas y planificadores sociales, divertían a grandes sectores de la juventud de la ciudad o del campo de los trabajos útiles a la sociedad, para entregarlos a la curiosidad de unos estudios de gramática sin ninguna proyección social (p. 817).

Será esta "deformación" educativa, de unos preceptores sin rumbo académico ni social, la que criticarán y satirizarán con saña jesuitas, como Isla, o intelectuales ilustrados como Vegas y Quintano.

A pesar de que la "política docente de los primeros Borbones fue restrictiva en relación con las Escuelas de Gramática, fuesen municipales o privadas, por entender que su proliferación era incompatible con el progreso de la agricultura" (Aguilar Piñal 1998, p. 229), por eso mismo, de todas las instituciones referidas que impartían la lengua latina, destacaban, por su abundante número de alumnos y por la calidad de su enseñanza, las escuelas y seminarios de jesuitas ${ }^{12}$, que con su expulsión en 1767 pasaron a ser controlados por los escolapios ${ }^{13}$. Precisamente, el ascendiente educativo que adquirieron los ignacianos provocó que arremetieran contra todo entrometimiento que consideraran que pudiera perjudicarles en su predominio y control educativo. Posteriormente a la expulsión de la Compañía serán los intelectuales y preceptores ilustrados los que se arrogarán el derecho de proteger la lengua del Lacio contra todo conato "intruso" que pudiera perjudicar su enseñanza y los que se eri-

12 "No obstante, las escuelas de gramática clásicas siguen funcionando, aunque pierden buena parte de su matrícula a favor de las escuelas municipales y de las de jesuitas" (Negrín Fajardo 2009, p. 240).

${ }_{13}$ Aunque jesuitas y escolapios eran las principales órdenes que "rivalizan durante el siglo XVIII por el control de los estudios humanísticos", no debemos olvidar que otras órdenes, "como los dominicos, mercedarios, carmelitas, benedictinos, trinitarios, ofrecían también la posibilidad de seguir estudios a los seglares en los colegios destinados principalmente a la formación de sus propios miembros, pero en número muy limitado, sin gran incidencia en el conjunto nacional" (F. Aguilar Piñal 1988, p. 232). 
girán como garantes de los poderes reales para aplicar su control educativo. Así pues, por ese afán regulador propio de la Ilustración se pretenderá oficializar la labor educativa de estos preceptores privados a través de pruebas de capacitación impartidas por la Real Academia grecolatina matritense, institución organizada por quince preceptores de latinidad de diferentes procedencias académicas, que alcanzó su Real Cédula el 10 de agosto del año de $1755^{14}$.

Tanto en jesuitas como, posteriormente, en preceptores y profesores ilustrados, la sátira gramatical sobre el profesor de latín constituye un buen instrumento de ataque contra ese "intrusismo" de aquellos sectores que eran considerados "obstáculos" educativos. Así, por ejemplo, el padre Isla arremeterá contra los profesores particulares de pueblos y villas que pertenecían al grupo de los "leccionistas" mencionados, normalmente alumnos "rebotados" de los propios colegios jesuitas con escasos conocimientos de latín, que deformaban las mentes de los niños y los encaminaban, en la mayoría de los casos, a rellenar el gran agujero de pretenciosos predicadores. Por otro lado, Vegas y Quintano, desde el plano ilustrado, también arremetía contra ese tipo de enseñantes provincianos atribuyendo su mal latín a los farragosos manuales y métodos de los maestros jesuitas.

Por eso mismo, tanto Isla como Vegas y Quintano satirizaron la figura del "preceptor privado", aunque Vegas y Quintano la aprovechó para denostar la enseñanza barroca de los jesuitas. En este punto no podemos obviar el feroz enfrentamiento educativo que existió entre jesuitas e intelectuales ilustrados. Los primeros controlaban la educación desde el siglo XVI, aproximadamente, y sometieron la enseñanza de la lengua latina a sus criterios pedagógicos basados, casi exclusivamente, en la gramática de Álvarez, en la del citado Juan Luis de la Cerda, y en una profunda "retorización"15 de la enseñanza que buscaba la exaltación divina y católica a través de un latín profundamente recargado de reglas, excepciones y ejemplos poco clásicos, y contaminado de hispanismos, detalles que también Forner

14 Sobre la Real Academia Latina Matritense, se deben consultar los estudios de Aguilar Piñal 1968; Luis Gil 1981, quien le dedica dos capítulos; y muy especialmente los de F. García Jurado y P. Hualde Pascual 2004 y 2005, en que dedican al asunto dos extensos artículos de investigación.

15 Analizamos el concepto "retorización” en J. EsPino MARTín $2015 \mathrm{a}$. 
criticará con saña del latín de Juan de Iriarte ${ }^{16}$. Por su parte, el movimiento ilustrado empezó a erigirse como una alternativa modernizadora que ensalzaba la enseñanza de asignaturas más científico-técnicas como matemáticas, física o biología, además de la historia, las lenguas modernas y el aprendizaje de artes y oficios ${ }^{17}$. El latín se veía como lengua del Antiguo Régimen y como lengua especialmente religiosa. Por eso mismo, los ilustrados empezaron a ver la necesidad de que la relevancia casi exclusiva que tenía en el modelo educativo jesuita se perdiera y, por oposición, se diera más importancia al español y a las lenguas modernas ${ }^{18}$.

El padre Isla era un jesuita simpatizante con parte del método de enseñanza ilustrado, ya que era uno de los humanistas que pertenecía al círculo reformista jesuita de la escuela-seminario de Villagarcía de Campos, que durante la segunda mitad del siglo XVIII arremetió contra el latín aberrante del barroquismo ${ }^{19}$. Paradójicamente, Vegas y Quintano emplea el preceptor de pueblo para criticar "racionalmente" ese latín deformado

16 Acerca de la enseñanza de latinidad barroca, ejercida especialmente por la Compañía de Jesús entre los siglos XVII y XVIII, véase EsPINo MarTín 2004.

17 Un ejemplo de esto es la fundación de las Sociedades Económicas de Amigos del País, que pretenden "promover la educación, la beneficencia, la industria y la agricultura, e integradas por miembros de la nobleza, del clero, de la magistratura y burocracias, y por personas acomodadas" (A. VIÑAO 2009, p. 284). Éstas ofrecían la alternativa para el modelo educativo ilustrado de enseñanza frente a las casi obsoletas escuelas de latinidad que representaban más el Antiguo Régimen o la estructura de la Iglesia contrarreformista. Al respecto es interesante este estudio de Antonio Viñao, puesto que analiza el estilo particular de la educación ilustrada que por sus ideales patrióticos, nacionalistas y cívicos anticipará los modelos educativos liberales del siglo xIX.

18 "Precisamente, el siglo xviII es testigo de un progresivo forcejeo polémico entre la lengua «madre» —el latín-y su «hija» romance —el castellano- por conservar o adueñarse, en su caso, la dignidad de idioma apto para las especulaciones de la filosofía o de la ciencia. En el fondo, no es más que la batalla por sobrevivir de una forma de vida medieval, de supremacía eclesiástica, frente a la nueva concepción de una sociedad secularizada. Batalla que no terminará con el triunfo definitivo del castellano hasta la reforma general de la enseñanza proyectada en 1813" (AgUiLAR Piñal 1988, p. 228).

${ }^{19}$ Isla hace alusión a Villagarcía cuando Antón Zotes no se decidía a dónde mandar a su hijo para que aprendiera gramática, a lo que la tía Catanlá se niega por la rigurosidad moral de los padres que regentaban el colegio (IsLA 1995, p. 282). El jesuita mantenía importantes contactos con el seminario de Villagarcía de Campos, donde él había estudiado, y con su rector, en ese momento, Francisco Javier de Idiáquez (véanse estudios sobre el seminario de Villagarcía, como F. Pérez Picón 1983 y J. Espino Martín 2012, pp. 82-97). 
proveniente del barroquismo que considera jesuita (si bien alaba el reformismo ignaciano de Villagarcía de Campos y la enseñanza de los padres escolapios).

Seguidamente, desarrollaremos, a través de una selección de textos, las diferentes características de la "sátira gramatical" que conformaron tanto el padre Isla en su obra de Fray Gerundio Campazas alias Zotes, como Manuel de Vegas y Quintano, en su Gramática y conducta del dómine Don Supino. Ambos ofrecerán dos perspectivas institucionales, la religiosa jesuita y la universitaria ilustrada en su uso de la sátira contra el enseñante de latinidad "a-institucional", caracterizado por su ignorancia, barroquismo y pedantería.

Fray GERUNDIO dE CAMPAZAS (1758-1771)

En la obra del padre Isla se mezclan, en principio, dos aspectos de los antes reseñados para el género satírico ${ }^{20}: 1$ ) la pars destruens y la caricaturización carnavalesca, y 2) la pars construens y el factor didáctico-moralizante en el que destaca, especialmente, el Fray Gerundio. En primer lugar, la pars destruens carnavalesca la apreciamos en la visión desoladora que da el jesuita de los enseñantes de latín a través de dos elementos fundamentales: a) la visión caricaturizada de la imagen de los preceptores y de sus nombres, y b) los aspectos escatológicos y bufonescos de su enseñanza. En segundo lugar, la pars-construens didáctico-moralizante se observa en el contraste entre la mala, farragosa y decadente enseñanza de la lengua de estos dómines manipuladores de la realidad y la claridad del "docto y clasicista" aprendizaje de La Compañía o del propio padre Isla. Como afirma Rebecca Haidt (2002, p. 27),

20 Sobre la sátira del padre Isla, Joe L. PALmer ha escrito dos interesantes estudios; el primero dedicado al origen de la sátira en el autor jesuita (1973); el segundo (1971), especialmente a la sátira social y educativa del Fray Gerundio. Cabe destacar, además, el libro de J. Снем Sнам 1999, que dedica a la corrupción del lenguaje que produce la sátira. Por último, se puede consultar la visión de Uzcanga (2001, pp. 429-435), que considera que la sátira de Isla se desarrolla para evitar "un grave problema que no ha podido ser resuelto por medios habituales", que sería el de la pedantería barroquizante de la enseñanza y predicación de otras órdenes religiosas como, por ejemplo, la de los capuchinos, que se sentirá especialmente agraviada y ofrecerá a través de fray Marcos Marquina una fuerte "contra-crítica" al jesuita. En este aspecto, también se podría ver la sátira de Isla como una diatriba entre órdenes religiosas, al estilo de las enemistades entre "hombres de letras" dieciochescos. 
el tipo de sátira que utiliza el autor del Fray Gerundio en su obra pretende seguir la estela de Cervantes y se sustenta en "series of dialogues", que tienen como ideal "means of inquiring into and figuring «reality» with all its multivalence", es decir, tanto "the worst of fools and the wisest of persons rely on the very same words to govern, to learn, and to dream"; y para tal fin usan "overlapping rhetorics", con que reconfiguran la realidad y hacen que lo imposible se vuelva realizable a través de un lenguaje manipulado y tergiversado, como sucede en las enseñanzas del dómine Taranilla o Zancas-Largas en Gerundio, que plantarán en él la semilla de "the unreliability of the means of representing reality through language", que se convertirá en el fruto de su predicación futura y de su capacidad para transformar la realidad con sus fascinadoras palabras y locuciones latinas.

En el siguiente pasaje podemos apreciar los rasgos anteriores en la sátira de las enseñanzas, los comportamientos y el lenguaje retórico manipulador del dómine Taranilla, un profesor pueblerino y provinciano, pero que pretende aparentar ser afrancesado y pedante. El padre de fray Gerundio, Antón Zotes, recibe de su hermano una dedicatoria de un fraile joven, escrita en un latín horrible ${ }^{21}$, vacío, hueco y sin sentido, pero que para Zotes está escrito con "estupendísima elegancia", de tal forma que la aprendió de memoria y hacía ver que era suya. Todos los que lo escuchaban lo tenían por aquella dedicatoria como grande latino y se lo comparaba con el dómine Taranilla, "aquel famoso dómine que atolondró a toda la Tierra de Campos con su latín crespo y enrevesado". Isla hace, a continuación, una detallada descripción de la primera frase de la carta (por cierto engañosa y de doble sentido ${ }^{22}$ ) con que el maestro examinaba a sus alumnos:

${ }^{21}$ Este latín con el que Isla pretende criticar la ignorancia de predicadores y frailes se derrocha ingentemente a lo largo de toda la obra del jesuita en las reglas para hacer sermones de fray Blas y los propios sermones de fray Gerundio. Según A. Torres-Alcalá (1984, p. 152): "No se trata, como a veces se ha insinuado, de un latín macarrónico - aunque se hermane funcionalmente con aquél一, ni tampoco formal, aunque se le parezca. Es simplemente un contrasentido lingüístico, y la única relación que observa con el macarrónico es la de atenerse al mismo código discursivo: el paródico. Todo ese «parrafazo» altisonante [refiriéndose a uno de los sermones de fray Gerundio] es una sátira-paródica del latín de púlpito, en el que la única semántica perceptible es el sonido: la palabra-timbre. Es decir, el eco de una cita”.

${ }^{22} \mathrm{Al}$ respecto, son conocidas en las historias de la enseñanza del latín frases que se parecen engañosamente a frases castellanas, como tua mater mala burra est o agricola cara coles. Así, por ejemplo, el propio Cervantes (1980, 
...como, verbigracia aquella famosa carta con que examinaba a sus discípulos que comenzaba así: Palentiam mea si quis, que unos construían, si alguno mea a Palencia y, por cuanto esto no sonaba bien y parecía mala crianza con peligro de que se alborotasen los de La Puebla y no era verisímil que el dómine Taranilla — hombre, por otra parte, modesto, circunspecto y grande azotador- hablase con poco decoro de una ciudad, por tantos títulos tan respetable, otros discípulos suyos lo construían de este modo, si quis mea... - "Chico mío", suple fuge, "huye", Palentiam "de Palencia". A todos estos los azotaba irremisiblemente el impitoyable Taranilla; porque los primeros perdían el respeto a la ciudad y los segundos le empullaban a él sobre que, unos y otros, le suponían capaz de hacer un latín que, según su construcción, estaría atestado de solecismos. Hasta que, finalmente, después de haber enviado al rincón a todo el general porque ninguno daba con el recóndito sentido de la enfática cláusula, el dómine, sacando la caja, dando encima de ella dos golpecillos, tomando un polvo a pausas sorbido con mucha fuerza, arqueando las cejas, ahuecando la voz y hablando gangoso reposadamente, la construía de esta manera: "Mea, «ve», si quis, «si puedes», Palentiam, «a Palencia»". Los muchachos se quedaban atónitos, mirándose los unos a los otros, pasmados de la profunda sabiduría de su dómine; porque, aunque es verdad que, echada bien la cuenta, había en su construcción, mitad por mitad, tantos disparates como palabras — puesto que ni meo, meas significa como quiera ir, sino ir por rodeos, por giros y serpenteando, ni queo, quis significa poder como quiera, sino poder con dificultad-, pero los pobres niños no entendían estos primores; ni el penetrar la propiedad de los varios significados que corresponden a los verbos y a los nombres, que parecen sinónimos y no lo son, es para gramáticos de prima tonsura ni para preceptores de la legua (Isla 1995, pp. 240-241).

Vemos que lo carnavalesco aparece ya en el propio nombre del dómine ${ }^{23}$ en la traducción escatológica que dan algunos

p. 308) emplea este tipo de frases en el Coloquio de los perros cuando hace referencia a un poeta "tonto y académico de la Academia de Imitadores": "Deum de Deo; y respondió que dé donde diere".

${ }^{23} \mathrm{El}$ aspecto carnavalesco de los retratos y los nombres propios los ha estudiado específicamente Martínez Fernández 2000. El autor (p. 288) sigue a Barthes para señalar que el nombre propio es el "príncipe de los significantes" y que "sus connotaciones son ricas, sociales y simbólicas". En los retratos de los personajes del Fray Gerundio, los nombres propios tienen la misma "función paródica" que el "mote", "al destacar una condición o manera de ser". El uso paródico de los nombres propios, como si de un mote se tratara, entraría dentro del lenguaje carnavalesco para Bajtin. Así pues, 
niños a la frase que propone Taranilla como examen, y, por último, en la pose exagerada y arrogante que toma el preceptor cuando absorbe los polvos antes de exponer la solución de la enigmática frase. En esto último podemos observar, por la descripción tan teatral y tan caricaturizada que hace Isla de la actitud pedantesca y afrancesada del preceptor, un guiño del autor del Fray Gerundio a las comedias de Molière ${ }^{24}$ en su crítica a los pedantes y a los petits-maîtres en obras como El burgués gentilhombre o El médico a palos.

A estos rasgos carnavalescos se une la pars construens del factor didáctico-moralizante, propio de la sátira dieciochesca y de la novela de formación (puesto que el Fray Gerundio se puede considerar una novela de formación "carnavalesca"), como tenemos ocasión de ver al final del pasaje, cuando Isla alecciona al lector sobre los verdaderos significados de los términos que ha utilizado Taranilla para componer su frase. El jesuita demuestra sus buenos conocimientos en la lengua latina, que después servirán para justificar indirectamente y convencer al lector de la "espléndida" enseñanza de La Compañía —en este rasgo se puede apreciar más el aspecto moralizante-y, en concreto, del colegio de Villagarcía de Campos, donde su rector, Francisco Javier de Idiáquez, puso gran empeño en la renovación clasicista del latín a través de la publicación de muchas ediciones de clásicos, cuidadas y muy didácticas, llenas de notas explicativas y observaciones aclaratorias.

La pars destruens se apreciaría por el afán de mostrar lo folclórico, lo escatológico y lo bufonesco que tienen las respuestas de los alumnos y la actitud del profesor, con el objetivo último de hacer reír simplemente, mientras que la construens se mostraría en el juicio de la censura de Isla acerca de los disparates que dice su personaje ${ }^{25}$, en un latín absurdo y altisonante cuyo

"la frontera entre nombres propios y comunes se debilita", de forma que los nombres van asumiendo "la cualidad de sobrenombres". Se convertirían en "nombres-apodo o nombres-definición", según Gracián, y perderían "su carácter neutro, pues incluyen siempre una idea apreciativa positiva o negativa".

${ }^{24}$ Sabemos que en la biblioteca particular de Isla destacaban las comedias de Molière como una de las lecturas principales del jesuita (cf. L. FERNÁNDEZ 1952, p. 138). El mismo jesuita cita al ilustre comediógrafo en el Prólogo del Fray Gerundio (1995, pp. 197-198). También ha resaltado esta influencia en su obra, B. Gaudeau 2010, p. 292.

25 Acerca del hecho de mezclar la seriedad con la risa, Zavala (1987, pp. 84-85) dice lo siguiente: "Si aceptamos las categorías establecidas por Bajtin, Isla creó una construcción híbrida; en tales discursos se contraponen 
mejor reflejo está en los sermones de Gerundio ${ }^{26}$. Sin embargo, una lectura detenida del pasaje sugiere que el objetivo principal de Isla no sólo es hacer reír con los elementos ridículos de la escena $^{27}$, sino que, a partir de ahí, la lección moral se desprende por sí misma y se refuerza ${ }^{28}$ (y no tanto por su toque erudito, que reprende la ignorancia de la frase del dómine). La pars construens ilustrada de Isla se dirige no tanto a una didáctica cartesiana como la que pretenderá aplicar Vegas y Quintano, sino a una enseñanza moralizante que regenere el panorama educativo tanto moral como educativo de las órdenes eclesiásticas. Como simpatizante ilustrado, Isla pretende la reforma institucional y social; como jesuita, que esa reforma se aplique a la Iglesia y sus feligreses.

Estos rasgos que hemos visto en Taranilla continúan en el preceptor de latinidad de fray Gerundio, el dómine Zancas-Largas. Éste, al igual que Taranilla, recibe una imagen ridícula y bufonesca de su enseñanza barroca y grandilocuente, donde se mezclan los aspectos carnavalescos con los propiamente didáctico-moralizantes, que reivindican el papel educativo de La Compañía de Jesús. No obstante, es precisamente en la descripción fisiognómica de este dómine donde Isla emplea la técnica reductiva y caricaturizadora, muy semejante a la caracterización del licenciado Cabra del Buscón de Quevedo ${ }^{29}$ :

dos lenguajes: el del sentido común, «opinión general» o «buen gusto», y el de los profesionales de otras clases sociales".

26 Para Martínez Fernández (2000, p. 286) el uso de este tipo de recursos lingüísticos ("lenguaje popular, argumentos silogísticos absurdos, en las citas heréticas y ridículas...") entra dentro de una sátira "agresiva, negativa, ajena, en cierto modo, a lo que Bajtin entiende por parodia carnavalesca, festiva, popular, universal y ambivalente”. Según Martínez Fernández, el mundo entero no puede ser cómico para Isla, porque los mira "desde el distanciamiento culto, desde la visión esperpéntica avant la lettre, con una tajante diferenciación entre lo cómico y grave".

27 "El jesuita escribe en comunicación directa con la cultura de la risa que se nutre de la parodia sacra y la escritura chistosa o género burlesco" (ZAVAla 1987, p. 88).

28 Como afirma Zavala (1987, p. 90), "el marco de carnavalización le permite reforzar la lección moral".

29 Según señala Martínez Fernández 2000, p. 287. Ya Sebold (desestimado por Jurado) afirmaba que existe una cercanía entre el licenciado Cabra del Buscón de Quevedo y el dómine Zancas-Largas. No obstante, aunque exista o no esta relación de facto, más adelante aclara que el retrato físico de ambos dómines parte de "tradiciones populares que, junto a modelos 
Era éste un hombre alto, derecho, seco, cejijunto y populoso; de ojos hundidos, nariz adunca y prolongada, barba negra, voz sonora, grave, pausada y ponderativa; furioso tabaquista, y perpetuamente aforrado en un tabardo talar de rayada, que en su primitiva fundación había sido negro, pero ya era del mismo color que el tabardo. Su conversación era taraceada de latín y romance, citando a cada paso oradores, historiadores y gramáticos latinos antiguos y modernos, para apoyar cualquier friolera (p. 283).

Junto a su fisionomía carnavalesca, Zancas-Largas muestra la enseñanza de un latín casi más decadente y macarrónico que el del propio Taranilla, debido al lamentable método gramatical que emplea. En el siguiente pasaje en que Zancas-Largas dialoga con Antón Zotes critica "irónicamente" el método jesuítico porque emplea abreviaturas en las terminaciones de los casos y no la palabra completa declinada. De esta forma, se perjudica el aprendizaje de los niños, así como la recta composición en latín. Ésta es una pequeña muestra de cómo Zancas-Largas pone de manifiesto una forma de enseñanza que se pierde en cuestiones absurdas, sin sentido e innecesarias en el buen aprendizaje de la lengua latina:

-Ecce tibi sebosus. Ve aquí uno de los errores tan crasos como velas de sebo, que yo noto en este arte de Lebrija o de la Cerda, de que usan los padres de la Compañía con quienes también estudié yo. Es cierto que son varones sapientísimos, pero son hombres, y hominum est errare: son agudos, son buenos ingenios y muy despiertos, pero muy despierto y muy bueno fue el ingenio de Homero, y con todo esto quandoque bonus dormitat Homerus. Lo primero comenzar la gramática por musa, musae es comenzar por donde se ha de acabar: coepisti qua finis erat, porque las musas, esto es, la poesía, es lo último que se ha de enseñar a los muchachos, después de la retórica. Argumento es éste, que le he puesto a muchos jesuitas, clarísimos varones, y ninguno ha sabido responderme. Pero, ¿qué me habían de responder, si no tiene respuesta? Deinde, en la impresión de muchos artes, en lugar de poner: nominativo: musa; genitivo: musae, dativo: musae, acusativo: musam, todo a la larga y por extenso, por ahorrar papel lo ponen en abreviatura: nom.: musa; gen.: ae, dat.: ae, acus.: am. ¿Y qué sucede? O que los pobres chicos lo pronuncian así, quod video quam sit ridiculum; o que sea menester gastar tiempo malamente en enseñárselo a pronunciar;

específicamente literarios, suponen estímulos menos evidentes para el crítico literario y proceden de diferentes creencias antropológicas". 
et nihil est tempore pretiosius. Pero donde se palpan ad oculum los inconvenientes de estas abreviaturas son en los Tesauros, ya sea de Salas, ya de Requejo. Va un niño a buscar un nombre, exempli causa: qué hay por madre; y en lugar de encontrar mater, matris, halla, mater, tris. Quiere saber qué hay por enviar; y en vez de hallar mitto, mittis, encuentra mitto, is. Busca qué hay por camisa; y en lugar de subucula, subuculae, no lee más que subucula, ae. Antójasele, como al otro muchacho, escribir a su madre una carta latina, para darla a entender lo mucho que había aprovechado, en la cual la dice que la envía una camisa sucia para que se la lave, y encájala esta sarta de disparates: Mater tris, mitto is, subucula ae, ut lavo as. Quid tibi videtur? ¿Qué le parece a vuestra merced, señor Antón Zotes? (p. 288).

Por otro lado, Isla (p. 290) afirma que su "barroquización" se percibe porque prefieren los autores clásicos más pomposos y afectados (Amiano, Plinio el Mozo, Valerio Máximo, Séneca, etc.) a los considerados tradicionalmente como referentes de la elegancia y la solemnidad de la lengua latina (Cicerón, Tito Livio, Virgilio, Catulo, etc.). El momento culminante del tipo de latín que enseña a sus alumnos se puede apreciar en los rocambolescos títulos de algunos libros (ni siquiera pertenecen a ninguna de las obras de los autores clásicos citados) que mostraba como manifestaciones álgidas del buen latín. El padre Isla aprovecha este título para analizar pormenorizada y didácticamente los disparates que describe:

Para él no había cosa como un libro que tuviese título sonoro, pomposo y altisonante, y más si era alegórico y estaba en él bien seguida la alegoría. Por eso hacía una suprema estimación de aquella famosa obra intitulada Pentacontarchus, sive quinquaginta militum doctor; stipendiis Ramirezii de Prado conductus, cujus auspiciis varia in omni Litterarum ditione monstra profligantur, abdita panduntur, latebrae ac tenebrae pervestigantur, et illustrantur. Quiere decir: "E1 Pentacontarco, eso es, el capitán de cincuenta soldados, a sueldo de Ramírez de Prado, con cuyo valor y auspicio se persiguen y se ahuyentan varios monstruos de todos los dominios de la literatura, se descubren cosas no conocidas, se penetran los senos más ocultos, y se ilustran las más densas tinieblas". Porque si bien es verdad que el título no puede ser más ridículo, y más cuando nos hallamos con que todo el negocio del señor Pentacontarco se reduce a impugnar cincuenta errores que al bueno de Ramírez de Prado le pareció haber encontrado en varias facultades, y no embargante de que a la tercera paletada se le cansó la alegoría; pues no 
sabemos hasta ahora que se hayan levantado regimientos ni compañías de soldados para salir a caza de monstruos ni de fieras, y mucho menos que sea incumbencia de la soldadesca examinar escondrijos ni quitar el oficio a los candiles, a cuyo cargo corre esto de desalojar las tinieblas; pero el bendito dómine no reparaba en estas menudencias, y atronado con el estrepitoso sonido de Pentacontarco, capitán, soldados y estipendio, decía a sus discípulos que no se había inventado título de libro semejante, y que era el modo de bautizar las obras en culto y sonoroso (p. 290).

Por ello, en definitiva, el contraste entre el latín de los dómines, que Isla nos retrata con tanta brillantez, y el que el propio jesuita defiende (la mayoría de las veces en tercera persona como narrador omnisciente) sumerge al lector en una curiosa oscilación entre lo macarrónico y lo clásico. Este latín barroco y deformado será el que plante la semilla de los "charlatanes" predicadores ${ }^{30}$, tan comunes en el siglo XvII, y que en el XvIII se va a satirizar y querer erradicar.

Pasamos ahora a la obra de Manuel de Vegas y Quintano, que representa la continuación directa y pleno desarrollo de la figura caricaturesca del maestro de latinidad del padre Isla, pero en boca de un catedrático universitario ilustrado.

\section{GRAMÁTICA Y CONDUCTA DEL DÓMINE DON SUPINO (1799)}

Vegas y Quintano fue catedrático de Latinidad en la Universidad de Alcalá de Henares durante la segunda mitad del siglo XviII, y en su obra Gramática del dómine Don Supino ${ }^{31}$ ofrece un panorama de la enseñanza de la lengua latina en que, al modo satírico que atribuye Haidt para el Fray Gerundio de Isla, establece un diálogo entre el dómine don Supino, que representa el aprendizaje barroco e irracional al estilo Taranilla y Zancas-Largas, y un "Crítico Preguntador", alter ego del propio Vegas y Quintano, que refiere una enseñanza ilustrada y racional, basado en los autores clásicos más puros y lógicos métodos de enseñanza.

30 Para el fenómeno general de la charlatanería entre eruditos e intelectuales, véase J. Álvarez BARRIENTos 2006, pp. 71-79; en concreto, para la charlatanería que desarrolla fray Gerundio a través de sus locuciones latinas y latinismos barrocos y absurdos, véase Luis de CAÑigral Cortés 1996.

31 Espino Martín 2015 es un estudio detallado de esta obra. 
Vegas y Quintano emplea tanto la pars destruens como la pars construens en su obra satírica; con la primera caricaturiza la figura del dómine en el personaje de don Supino ${ }^{32}$, en cuyo retrato se vuelve a hacer uso de los recursos carnavalescos o reductivos que utilizó Isla para la descripción fisionómica de Zancas Largas y que en don Supino acrecientan ese aire severo y temible, semejante a los antiguos maestros escolásticos medievales:

La marca de un Dómine, le dixe, si ser puede, ha de ser de dos varas y seis dedos, oreja grande, ancho de frente, undido de ojos, ceja larga, y espesa, de eminente nariz, ceñudo y áspero rostro, color cetrino, corpulentas manos, dedos como oregeras, gran muslo, igual pantorrilla, temibles fuerzas, y espantosa voz. Siempre serio, grave, indigesto, á ninguno risueño, aunque sea con su muger, y el desaliño en los Dómines les cae mejor que el soplamiento y curiosidad: y así debe afeytarse de mes á mes, que la mucha barba infunde respeto y terror: el gorro les asienta tan bien como una mitra á un Obispo, pero se ha de llevar torcido, porque esa postura demuestra mala condición. Es contra toda formalidad de los Dómines antiguos gastar pelucas, blondas, camisolas, chorreras, buelos, espadín, guantes, relox, evillones de plata, franjas de oro, vestidos de color profano, ni de seda. Vístase un Preceptor de gramática, un Dómine digo, todo de negro ó de pardo, color que les hace respetables, y respiran por todas partes autoridad y decoro, y disuena, desdice, es impropio en facultad tan seria esos perendengues ó peregiles que se han introducido en muchos de nuestra facultad (Vegas y Quintano 1790, pp. 25-26).

En cuanto a su método de enseñanza, el latín nefasto de don Supino se va intensificando a lo largo de la obra hasta un punto culminante, como se muestra en el pasaje en que Vegas y Quintano caricaturiza hiperbólicamente el mal latín del dómine:

Oiga Vmd. otras cositas tan buenas, tan importantes para los mayoristas, que no están en versos, y se las comen lo mismo que pasas, y valen un valer.

Aper ite ad vineas, quia ubas est: Id corriendo que un Jabalí se come las uvas ¡Esto si que es poquito y bueno! Al, pi, pen, $c a, n i$,

${ }^{32}$ Ya el propio nombre del dómine (Supino) implica, de nuevo, como vimos en Zancas-Largas, un nombre o apodo carnavalesco de la misma naturaleza gramatical que el "Gerundio" que protagoniza el Fray Gerundio de Campazas. El nombre de Supino "además de ser una forma nominal de un verbo en algunas lenguas indoeuropeas, tiene el significado común de «necio»" (MARTínez Fernández 2000, p. 289). 
nas, tot, bas, quot habet plumas. ¿Qué es esto, Señor Don Supino, me dixo con una cara de vinagre el Preguntador, ¿qué idioma?, ¿qué lengua y tartamudeamiento es ese? Esto es, le dixe, el latin mas desfigurado, mas obscuro, mas dificil é imposible de entenderse: solo nosotros lo sabemos, y lo compaginamos así, para entenderse: Pica habet tot pennas albas, quot nigras: que la picaza ó urraca tiene tantas plumas blancas como negras (p. 90).

Al final de su obra, el "Crítico preguntador" de don Supino se muestra desesperado al ver que todas las razones y justificaciones que ha pronunciado a lo largo del libro no han convencido al dómine para que cambie su horrible forma de enseñar la lengua de Cicerón:

Y si a los principios de mi historia amagaba con infortunios, pronostiqué lástimas, me creí perdido, como quien sale de un encanto, recobra el juicio, se sienta sereno, y se vé alentado, sin ponerse nada por delante, atropellando por todo, despreciando sátiras, desestimando razones, recobro mis créditos á pesar de tantos émulos, diciendo que: Yo soy Don Supino, Dómine Mazorral, Preceptor Macarrónico, inmutable en su ciencia: (Ego Dominus et non mutor, como se dixo en las honras de uno de nuestra profesión) perfecto en su Gramática, famoso en su conducta, ilustre en sus latines, inmortal en sus méritos, y honor de la Patria (p. 148).

No obstante, no podemos decir que su obra sea puramente destructiva, puesto que, llevado por el espíritu ilustrado y optimista de su centuria, el "Crítico Preguntador" expone las muestras de regeneración de los nuevos manuales que se publicaron después de la expulsión de los jesuitas, regeneración que habían intentado antes los citados jesuitas de Villagarcía de Campos al querer desterrar de España el latín barroco y todas aquellas frases y expresiones idiomáticas tan absurdas que pronunciaban los Taranilla, Zancas-Largas o don Supino:

Desde la extincion de la Compañía, todo curioso, todo crítico, todo sábio, todo hablador se ha metido á compositor de Artes, reformador de estudios, maestro de latinidad y Dómines muy reverendos... esos mismos Padres, en los últimos años de su vida, desterráron de sus estudios muchas nimiedades, quitando libros, mudando autores, suavizando el trabajo, y aliviando á los niños. Se deshiciéron de los compendios, y aun del mismo Padre Brabo, sin darles mas libro de gramática que el Arte, y unas platiqui- 
llas de oraciones de ocho hojas. Dexáron traducido á Fedro, y sesenta Cartas escogidas de Ciceron primorosamente: ilustráron con notas á Ciceron, Nepote, Curcio, Ovidio y Virgilio los Padres Idiazquez, Palomares, Navarrete y Petisco. Estos mismos desaprobáron y aborreciéron la costumbre y el permiso de oraciones que Vmd. confiesa por tan necesarias: y estaria atracándose de ellas, quando el tal Padre Idiazquez escribió éstas: Los bancos comiéron á lo bueyes: Subsellia manducaverunt bobes. La tia Calva, que tiene mal humor, vende castañas que vencen á Pedro: Avuncula Calva, quae habet malum humorem, vendit castaneas, quae vincunt Petrum; para asegurar y decir que no se les dexe á los niños formar ellos las oraciones, sino que se las den los Maestros buenas y utilísimas. Ninguno de los nuevos documentos y plataformas de instrucciones me ha cogido ignorante, y sin noticias muy anteriores de hombres sapientísimos. Y así, como quien vuelve la hoja, me gusta decirle, que Ciceron tiene con abundancia suavísimos preceptos para todo género de gramáticos: para principiantes, para adelantados, para el mas mínimo del aula, para el mayor de ella: para niños de fuerzas débiles, de ingenio claro, de tarda comprehension, de mucha capacidad: todos tienen y pueden aprehender, y todos logran abundante fruto porque á todos enseña Ciceron (pp. 58-59).

En este texto podemos observar lo que decíamos en el apartado anterior de que Vegas y Quintano achacaba, en gran medida, el barroquismo de la enseñanza de latín a los métodos jesuitas anteriores, que los "reformadores" de Villagarcía pretendieron eliminar. Junto con la propuesta de regenerar la enseñanza de la latinidad mediante el método de Villagarcía y el aprendizaje de Cicerón, Vegas y Quintano alude a la labor positiva de los padres escolapios, que "tenían sofocado" al dómine don Supino "con el encoplamiento de sus reglas", porque en las escuelas pías se aplicaba el método racional y cartesiano ${ }^{33}$. El catedrático ilustrado acaba haciendo en la Gramática del dómine Don Supino un análisis conciso de la enseñanza del latín en la España de su tiempo a través de autores, obras didácticas, gramáticas, etc., con el propósito de ensalzar y defender el método racional e ilustrado en el aprendizaje de la lengua del Lacio. Frente al autor del Don Guindo que, como veremos, muestra satíricamente las fallas del método ilustrado en la enseñanza del latín, Vegas y Quintano lo sublima para oponerlo a la "barroquización" que procede

33 Para más información sobre el método racionalista de la enseñanza del latín de los escolapios, véase Espino Martín 2003. 
de los excesos de la enseñanza jesuita y de los dómines "leccionistas" que la siguen.

En definitiva, Vegas y Quintano será el primer autor que, siguiendo los pasos y ecos de los autores precedentes, desarrolle la modalidad de la "sátira gramatical" en un libro entero. De este modo, se pasa de dedicar capítulos a esta modalidad (dentro de obras satíricas más amplias) a hacer que dicha modalidad adquiera carta de naturaleza y asiente sus rasgos fundamentales en la totalidad de una obra. Pero esta modalidad del género satírico (independientemente de aquellas obras literarias que hayan utilizado la enseñanza y los profesores de la lengua latina como mero recurso de ironía literaria) no concluirá en la obra de Vegas y Quintano, sino que continuará en el xix. Las muestras más curiosas son, sin duda, la obra titulada Los gramáticos, de Francisco Sánchez Barbero, donde se sigue denunciando la enseñanza degradada del siglo anterior, y el Curso completo de gramática parda, del bachiller Cantaclaro ${ }^{34}$ (nombre parlante y evidente pseudónimo burlesco). En esta obra se invierte el objeto satírico, pues la enseñanza de la gramática latina, antes blanco predilecto, se convierte en vehículo de una sátira contra la sociedad degradada de maleantes y engañadores. Estas dos obras merecen un estudio más detallado del que podríamos ofrecer aquí.

SÁTIRA GRAMATICAL Y LATINIDAD EN LOS "HOMBRES DE LETRAS" DIECIOCHESCOS: LA FIGURA DEL PROFESOR DE LATÍN EN LAS diatribas de Juan Pablo Forner y de Vera de la Ventosa

Si la sátira gramatical sobre el profesor de latinidad es empleada por Isla y Vegas y Quintano para arremeter contra un tipo de enseñante que amenazaba la educación institucional, ya sea la de la Compañía, ya sea la de las universidades carloterceristas, también esta modalidad literaria servirá para enjuiciar la labor de preceptores que ciertos intelectuales ejercieron, en su momento, en su ascenso hacia puestos relevantes dentro del panorama cultural político de la burocracia borbónica. Una gran cantidad de obras satíricas, entre las que destacan Los eruditos a la violeta (1772), de José de Cadalso, Los literatos en Cuaresma (1773), de Tomás de Iriarte, La derrota de los pedantes (1789),

34 Curso completo de Gramática Parda en quince lecciones ó vivir sin trabajar. Almarabu, Madrid, 1865 (versión facsimilar). 
de Leandro Fernández de Moratín, o la Metrificatio invectivalis contra studia Modernorum, cum Notis critico-scholasticis (1787), de Tomás de Iriarte reflejarán y criticarán un mundo de intelectuales arribistas que pretenden subir en el escalafón a través de la enseñanza y la crítica mordaz entre ellos ${ }^{35}$. De hecho, estas mismas obras, aparte de manifestar el aspecto satírico del mundo intelectual de la segunda mitad del siglo XviıI, también son instrumento de ataque contra aquellos competidores eruditos e intelectuales que puedan obstaculizar el ascenso social de sus mismos autores en el mundo de la cultura dieciochesca. Según señala Álvarez Barrientos (2006, p. 35), en el mundo cultural del siglo XviII existen dos tipos de intelectuales: por un lado, los "eruditos encerrados en su gabinete de estudio, que no sabían relacionarse con la sociedad y se volvían engreídos de sus conocimientos". Este tipo de "erudito" procede especialmente de los paradigmas culturales del siglo xviI y de la mentalidad barroca, obsesionada por atesorar conocimiento (un claro ejemplo se puede ver en el francés Bayle y su Dictionnaire historique et critique, 1697); por otro lado, los "literatos menos sabios pero más filósofos y capaces de estar en sociedad" (de ahí que el tipo de obra erudita por excelencia sea L'encyclopédie, 1751-1772, que más que recopilar conocimiento, como hizo Bayle, pretendía sistematizarlo y analizarlo). El hombre de letras dieciochesco es una evolución del humanista y gramático de siglos anteriores, ya que de "trabajar sin considerar al público, han pasado a ser hombres de letras", al aumentar el "número de materias posibles" y "ensanchar el mercado" con nuevos medios de difusión que nacen de la imprenta: periódicos, gacetas, etc. Por otro lado, pasan "de la crítica filológica, propia del gramático humanista", "al espíritu filosófico, es decir, la capacidad crítica", que "se aplicó en asuntos que, a la larga, iban a producir mayores efectos sobre la sociedad". Por eso el antiguo gramático se dedicaba a "errores filológicos e interpretaba textos", pero, transformado en "hombre de letras", "critica errores y supersticiones, y pro-

35 Estos enfrentamientos surgen en época de los "novatores", que debido a los cambios de tipo "historiográfico, lingüístico o filosófico — por no incluir los enfrentamiento ideológicos asociados, a fines de siglo y comienzo del siguiente, al cambio de dinastía y la Guerra de Sucesión-desencadenan debates apasionados, con multitud de publicaciones de mayor o menor extensión que tienden a configurar la existencia de dos campos habitualmente bien demarcados" (E. Martínez Mata y J. Pérez Magallón en su ed. de IRIARTE 2010, pos. 143 de 2142). 
ponía reformas que pudieran favorecer a la población"; de este modo, "extendían la duda y estimulaban la capacidad de pensar”, por lo que empleaban diálogos entre lectores lejanos para "dar pie a la conciencia de pertenecer a cierto grupo, también trasnacional, que pensaba de modo similar" (pp. 34-35).

Con los rasgos con que Álvarez Barrientos describe el contraste entre el erudito humanista y barroco y el "hombre de letras" dieciochesco, podemos comprender la unión evolutiva entre ambos y que existen puntos de comunión entre el gramático de latinidad y el intelectual dieciochesco; de hecho, veremos que Juan de Iriarte, gramático, bibliotecario y académico, simboliza la conjunción de ambos universos culturales ("la de preceptor solía ser una etapa en el cursus honorum de algunos hombres de letras, que desde allí y gracias a la influencia de sus señores o a sus propios oficios tenían la posibilidad de mejorar", p. 206). Así, esta confrontación gramático-hombre de letras ayuda a analizar con nuevos enfoques la sátira gramatical respecto al preceptor de latinidad. En esta perspectiva, en los casos de Isla y Vegas y Quintano, el tipo de preceptor que ellos caricaturizaban por sus ideas obsoletas y extravagantes respondía más al modelo del antiguo gramático pueblerino con un leve barniz de afrancesamiento. Por otra parte, Forner y Vera de la Ventosa harán lo contrario, satirizarán hiperbólicamente al nuevo hombre de letras, culto, sociable y cosmopolita que, por ello mismo, tildarán de "ignorante y pedante", cuando realmente era un violeto ${ }^{36}$, según el enfoque de Cadalso, "persona culta que había logrado sus conocimientos con menos esfuerzos que aquellos sesudos envidiosos, que, sintiéndose amenazados le ridiculizaban" ${ }^{37}$. El

${ }^{36}$ Precisamente, entre los preceptores más famosos, vueltos hombres de letras, Álvarez Barrientos (2006, p. 207) cita a Juan de Iriarte, preceptor del duque de Huéscar, después duque de Alba; a Felipe Scío de San Miguel de las Escuelas Pías, preceptor de la infanta Carlota Joaquina, y a Pérez Bayer, preceptor de los Infantes Reales, hijos de Carlos III.

37 Álvarez Barrientos (2006, p. 62) glosa a Cadalso y defiende violeto como "hombre de instrucción variada y menor que la de un erudito", "hombre que tiene otra cultura y sobre todo, otra actitud...". Sigue describiendo Álvarez BARrientos: "el violeto, pues, era el hombre que quería brillar en sociedad opinando, y mostrando su saber, pues eso se había convertido en una forma de atracción. Llamarle «erudito» formaba parte de la campaña de desprestigio y contra las novedades y era manipular el modo en que debía entenderse su papel reformador (confundiéndolo con los eruditos «charlatanes», porque se trataba del hombre que desde los salones divulgaba conocimientos e ideas, incluso si lo hacía apoyado en su vanidad, desde la 
violeto representaba una intelectualidad que no se basaba en "ignorancia y apariencia de saber" (p. 55), sino en una "manera distinta de entender la cultura" (p.61). A ojos de Vera de la Ventosa y Forner resultaban ser más bien

un conjunto de ignorantes recubiertos con un ligero barniz de noticias superficiales e incoherentes, pero sobre todo con una pose ante los demás (como la que adoptan muchas veces los dómines de Isla y Vegas y Quintano) que tiende a superar externamente la íntima inseguridad mediante el control de gestos y mecanismos que la ocultan y la convierten en su contrario (cf. Iriarte 2010, pos. 188 de 2142).

En este panorama, las antiguas generaciones de "eruditos" se entremezclarán con las nuevas de "hombres de letras" (también llamados "philosophes") hasta el punto de representar una suerte de eclecticismo ${ }^{38}$, que sirve a Forner (visto él mismo como un buen "hombre de letras" moderno) para criticar, por ejemplo, el tipo de latín y la enseñanza de gramático y erudito obsoleto de Juan de Iriarte. En otras ocasiones, y aquí no lo analizamos, Forner se viste de erudito humanista y dirige su invectiva al sobrino, Tomás de Iriarte, que representa un claro símbolo del intelectual dieciochesco carlotercerista, por lo que Forner, envidioso de su éxito tanto literario como social, le tildará de "pedante" y le achacará falso conocimiento y apariencia del saber.

Bajo el pseudónimo de Vera de la Ventosa, el autor de $E l$ siglo ilustrado arremete contra Pablo de Olavide, tipo de intelectual dieciochesco "a lo Tomás de Iriarte", arribista y buen conversador en las tertulias, las cuales representaban los focos de encuentros tanto cultural como social de la nobleza e intelectuales ilustrados. La sátira gramatical esta vez servirá para ridiculizar los métodos de enseñanza que, o bien el satirizado, como en el caso de Juan de Iriarte, empleaba cuando ejerció como preceptor de la nobleza en su ascensión a bibliotecario real, o bien que recibieron los mismos satirizados cuando eran estudiantes de latinidad, como en el caso de Pablo de Olavide antes

superficialidad y la provocación del bel esprit, ofendiendo el gusto de literatos como Villanueva". Otro estudio relacionado con este último aspecto de la obra de Cadalso es el de J. Álvarez Barrientos 1999.

38 "Finalmente, don Juan es la personificación del erudito al servicio de la monarquía, y representa el vínculo entre la tradición y la nueva cultura" (M.A. Perdomo Batista 2010-11). 
de ascender a intendente de Sevilla ${ }^{39}$. De este modo, Forner utilizará la sátira-diatriba contra Juan de Iriarte a la vez que Vera de la Ventosa contra Pablo de Olavide. Seguidamente veremos cómo se despliegan ambas sátiras.

\section{EL SIGLO ILUSTRADO, VIDA DE DON GUINDO CEREZO (1777)}

La obra, de autor anónimo, oculto tras el pseudónimo de don Justo Vera de la Ventosa, es una "novela satírica con forma biográfica" ${ }^{40}$ donde el escritor se dedica a despotricar contra aquellas ideas ilustradas que por excesivamente "racionalistas" le parecían totalmente ridículas. Si bien El siglo ilustrado se basa en "estilo y situaciones, con Fray Gerundio de Campazas" ${ }^{11}$, no ataca, sin embargo, el barroquismo de la enseñanza del latín como lo hace Isla en su obra, sino que arremete contra el método racionalista e ilustrado proveniente de Francia.

El protagonista don Guindo podría ser el alter ego de quien constituye el centro de las críticas dentro de la obra, Pablo de Olavide $^{42}$, ministro y gobernador de la Bética en época de Carlos III, y que representa el modelo del ilustrado que, llegado del Perú (los llamados peyorativamente "indianos"), pretendía introducir en España todo aquello que "oliera a francés" y realizó una importante labor al reformar el plan de estudios de la Universidad de Sevilla en 1768 y modelarlo según el espíritu cartesiano y racionalista ${ }^{43}$. Aunque la obra aparentemente

${ }^{39}$ La sátira de Forner y de Vera de la Ventosa contra Juan de Iriarte y Pablo de Olavide, respectivamente, se hace especialmente intensa puesto que ambos proceden de una periferia muy alejada de la península (Canarias y Perú), que los lleva a acrecentar su presencia como hombres de letras en tertulias y lugares donde puedan exhibirse ante la alta sociedad. Este sustantivo afán de medrar va a desarrollar un profundo resquemor y envidia contra ellos.

${ }^{40}$ Michel Dubuis e Isabel Terán en su ed. de Vera de la Ventosa 2010, p. 9.

${ }^{41}$ Michel Dubuis e Isabel Terán, en su ed. de Vera de la Ventosa 2010, p. 11.

42 Véase gran parte del estudio introductorio de Dubuis y Terán, donde se explica esta comparación entre don Guindo y Pablo de Olavide (Vera DE LA Ventosa 2010, pp. 25-46). En adelante, cuando se mencione a don Guindo, se hará como "don Guindo/Olavide" para que el personaje histórico al que el nombre hace referencia, se identifique constantemente en estas páginas.

43 Sobre el plan de estudios de Olavide, véase el análisis de Aguilar PIÑAl 1969. 
se estructura y conforma como una "sátira ilustrada", "dirigida a encaminar a sus conciudadanos hacia la virtud intelectual y moral, para acercarlos al modelo ideal de hombre, que era el de ciudadanos de bien"44, acaba siendo una "invectiva satírica" (Ozuna Castañeda 2004, p. 82), a modo de diatriba, contra los violetos y contra todos los aspectos del racionalismo que en ella se estiman perniciosos para una adecuada enseñanza ${ }^{45}$. Con ello, Pablo de Olavide se vuelve un frívolo violeto, en parte a causa de ese pernicioso aprendizaje ilustrado del latín, igual que fray Gerundio salió un predicador charlatán por su aprendizaje barroco. De este modo, haciendo el uso habitual de toda sátira, de la "ironía", el "sarcasmo" y los "equívocos", El siglo ilustrado se dedica a desarrollar una "inversión de valores", basada en una "exaltación hiperbólica de lo moderno", que es "descrito como divertido, brillante, luminoso y de moda", y opuesto a la "degradación fingida de lo cristiano, pintándolo como aburrido, oscuro, fanático y en desuso" (p. 49). Igual que el Gerundio de Isla, el protagonista muestra una visión distorsionada de lo correcto, por lo que debemos entender que el mensaje que nos quiere dar el autor es contrario al mensaje que proporcionan el narrador y los protagonistas.

Del mismo modo que Gerundios y Supinos, Don Guindo sigue la estructura de la novela picaresca de formación que parte desde el aprendizaje de primeras letras y continúa hasta la universidad. Así pues, en estas etapas formativas se encuentra, como en las sátiras anteriores, la modalidad de la "sátira gramatical", que se muestra, en especial, en el cap. 3, titulado "Entra Guindo a estudiar la gramática con el precepto don Líquido. Progre-

44 Michel Dubuis e Isabel Terán, en Vera de la Ventosa 2010, p. 47.

45 Por este motivo, Aguilar Piñal 2009 considera que detrás del pseudónimo de Vera de la Ventosa podrían estar dos frailes intelectuales, al estilo de Isla y conocedores del método educativo ilustrado, el agustino fray José Gómez de Avellaneda y fray Fernando Cevallos, "prior de Santiponce", por el que más se inclina el estudioso: "sabio teólogo y furibundo activista contra la Ilustración", que se opondría a la reforma de la universidad sevillana de su "homónimo" Cevallos, "mano derecha de Olavide" (p. 326). Se debe al freno que pone Carlos III a las reformas y a la salida del Conde de Aranda de la presidencia del Consejo de Castilla (1773) la “«desaceleración» de las Luces", lo que "envalentona a quienes a ella [la Ilustración] se oponen, principalmente la Iglesia católica" (p. 325). Sobre todo, el sector eclesiástico más enfrentado a la Ilustración fue el de las órdenes mendicantes, ya que perdieron gran cantidad de sus privilegios económicos y sociales. 
sos que hace en la Latinidad". Don Líquido (de nuevo nombre parlante, de carácter carnavalesco que proviene etimológicamente de liquor 'fluir' y que se asemeja a loquor, en el sentido de que en el preceptor fluye "la enseñanza de las palabras") va a rellenar en Guindo/Olavide el "vacío de cierto magisterio rancio y del tiempo de Maricastaña", ya que su "erudición" era "verdaderamente vasta" y "se extendía por todas las facultades, que había estudiado profundamente en los ensayos de artes y ciencias de monsieur Carlencas”, "y cuya comprensión poseía más idiomas que la Torre de Babel, que tenía el Calepino de siete lenguas ad honorem y que no le faltaba nada de lo que tenía de sobra" (p. 93).

Aunque Vera de la Ventosa sólo describe el retrato anterior, podemos ver en él ya la presentación de aquellos afrancesados pedantes que Forner criticará en su diatriba contra los Iriarte y que presumían de seguir un método de enseñanza de muchas lenguas modernas y de modernizar el "rancio" panorama educativo; por cierto, panorama educativo basado fundamentalmente en la enseñanza jesuita que, por la inversión irónica, es vista por el autor del Don Guindo como adecuada y eficaz. Así pues, opone la enseñanza exclusiva del latín basada en Nebrija y Arias Montano, que "dentro de poco se quedarían en mantillas", al aprendizaje de hablar "lenguas [modernas, se supone]" que "ellos [Nebrija y Montano], no supieron ni pudieron saber" (p. 94).

De este modo, don Líquido le advierte al niño Guindo/Olavide que "de ningún modo trajese el Arte de Luis de la Cerda (cosa que había perdido tan floridos ingenios como se ve en los españoles del pasado siglo)" y que

en su lugar podía buscar el Arte de Iriarte, cuyas alegres coplas hacen a los muchachos desde luego retozones y muy distantes de aquella prolija gravedad de los pasados tiempos y en cuyo estudio, como el nuevo método de Ortigosa, hacen los muchachos unos progresos cual no los tuvieron los romanos en el siglo de Augusto,

el cual no tiene que ver "con lo augusto de nuestro siglo" (id.). Además de ello, don Líquido consigue avanzar en el aprendizaje de tal forma que obtiene que don Guindo/Olavide diese "al mismo tiempo lecciones de hebreo y griego para lograr, que sin ir a Alcalá, fuese trilingüe, aunque hablando con más propiedad, mejor fuera llamarle exlingüe". Por último, don Líquido había añadido tales "sobrepuntos" (acotaciones) a la gramática 
latina "que llenarían de admiración a Antonio de Nebrija y al Brocense" (pp. 94-95).

Como podemos apreciar en lo antedicho, el autor de Don Guindo arremete contra la enseñanza tradicional de los jesuitas y la contrapone a la ilustrada, basada en los Nouvelle méthode pour apprendre (la langue latine, grecque, italienne, o française, entre otras) del port-royalista francés Claude Lancelot, que pretendía aplicar las ideas cartesianas y racionalistas a la enseñanza de la gramática. Aunque Lancelot publicó sus Métodos a mediados del siglo XVII, su obra ejerció especial influencia en España, cuando Carlos III deroga, en 1768, el decreto de 1599 que oficializaba el Arte de Nebrija, refundado por el jesuita Juan Luis de la Cerda, como manual único de la enseñanza de la latinidad. Con la expulsión de los jesuitas en 1767, sus manuales caen en profundo desprestigio y las ideas port-royalistas se imponen, de modo que a raíz del decreto de 1768 se produce un boom de manuales (cf. supra la alusión a este boom) y métodos que pretenden enseñar el latín en poco tiempo de forma sencilla, lúdica y ágil ${ }^{46}$. Por este motivo se citan la gramática de Iriarte ${ }^{47}$ y el método de Ortigosa $^{48}$. Ambas obras siguen el modelo port-royalista, el cual propugna un aprendizaje del latín más sencillo, breve y agradable para el alumno, de ahí, en referencia a estas obras, el uso irónico de "linda gracia" y su comparación sarcástica con los gramáticos tradicionales, empleados por la Compañía, como Nebrija y, en menor medida, el Brocense ${ }^{49}$. Por último, vemos

${ }^{46}$ Sobre el método, la historia y la influencia de las gramáticas de PortRoyal, tanto en Francia como en España, durante el siglo XVIII, véase EsPINO MARTín 2010.

47 Gramática latina escritas con nuevo método y nuevas observaciones en verso castellano con una explicación en prosa, Madrid, Imp. de Pedro Marín, 1771. Véase M.E. DE CuyÁs y Torres 1992.

${ }^{48}$ Fray Fernando de Ortigosa, Méthodo de enseñar la lengua latina con más utilidad, y en más corto tiempo, que el consumido por lo común de dos siglos acá, Antonio Marín, Madrid, 1767. La referencia a Ortigosa, que fue arzobispo de México, muestra la consideración que tenía el autor del Don Guindo hacia la Nueva España. De hecho, esta obra ejerció una influencia relevante en las obras del mexicano Lizardi, El Periquillo Sarniento y Don Catrín de la Fachenda (Vera de la Ventosa 2010, pp. 76-80). Precisamente, he desarrollado un estudio sobre la sátira gramatical de estas obras que coinciden, en gran medida, con algunos rasgos que se muestran en Don Guindo (EsPino MARTín 2013).

49 Acerca de la importancia de Nebrija sobre el Brocense en la educación jesuita, a la vez que la fundamentación de este último en la gramática racionalista de Port-Royal, véase Espino MarTín 2010a. 
una exaltación de lo "moderno" y, por ende, de sus métodos de enseñanza, con la referencia sarcástica de "nuestro augusto siglo" por "el siglo de Augusto".

El ataque al método jesuita de enseñanza lo observamos a través de los autores que el discípulo debe emplear: Virgilio, "nada tiene de apreciable a excepción de aquel bello espíritu con que adulaba a César"; Ovidio es "hombre funestísimo" y sólo induce a leer el "Ars amandi, porque en él nada hallaréis violento, antes todo muy natural", ya que en "aquel arte todo está lleno de humanidad". El discípulo tampoco debería aprender a ser retórico en las "Selectas de Cicerón y otras pamplinas de esta clase", ya que la elocuencia que allí se muestra "no sirve de modelo a los retóricos de estos días". En cuanto a otros poetas y oradores puede "entrar y salir" como quisiera, teniendo presente

las lecciones que para este punto dejó escritas el autor de Los eruditos a la violeta, entre los cuales vos os contaréis algún día, que si bien es verdad que han creído muchos que habló con ironía, yo no me puedo persuadir de ello, no siendo de creer que a vista de todo el mundo había de hacer burla de lo más de él (p. 95).

Don Líquido arremete contra todos aquellos autores latinos que fueron canónicos para los jesuitas: Virgilio, o Cicerón; en el caso de Ovidio, se enseñaban los Tristia y Ponticas; sin embargo, don Guindo/Olavide propone el Arte de amar, que por su carácter inmoral estaba totalmente descartado de la enseñanza ignaciana. Del mismo modo, propone a su discípulo que los demás poetas y oradores los aprenda libremente según el modelo de Los eruditos a la violeta - afirmación con que ataca la expurgación y selección moral de los jesuitas, la denominada virtus litterata. Si el discípulo sigue todos estos pasos, afirma, se convertirá en un "erudito" de los de la obra de Cadalso, es decir, acabará convirtiéndose en un "hombre de letras" dieciochesco o en un violeto, con toda la carga peyorativa que ello conlleva.

Según estas enseñanzas, ya don Líquido en dos meses podía intentar hacer una traducción de Horacio, "ponerle unas notas a Virgilio y formar reflexiones sobre Cicerón". También don Guindo/Olavide aprendió el griego y finalmente presentó sus logros latinos en sociedad y, al igual que en el Fray Gerundio cuando Gerundio predicaba a personas conocedoras del latín, "no sólo causaron espanto, sino asombro" (p. 96). Don Guin- 
do/Olavide expuso una "oración retórica" "que no le quedó por algunos días acción en el brazo derecho; le dio tanta alma que él rió, lloró e hizo cosas que si el mismo Tulio las viera, no hay duda que llorara a moco tendido o que riera a carcajada abierta”. El caso es que toda esa escenificación de la pedantería ilustrada quedó "tan propia del buen gusto de nuestro tiempo”, que causaría la profunda envidia de frailes y clérigos, pero "a Dios gracias que estamos en un tiempo en que sabemos que para todas estas cosas está de más el agua bendita" (id.). Con este final del capítulo, el autor de Don Guindo cierra de manera profundamente sarcástica su ataque contra el pedantismo ilustrado de su época. De este modo, si Isla satirizó los excesos del lenguaje barroco de los frailes, Vera de la Ventosa, quizás él mismo fraile, lo hace con la lengua del pedantismo ilustrado de los "hombres de letras", y pone a los frailes como eruditos espectadores. Seguidamente, analizaremos la "sátira gramatical" entre "hombres de letras" ilustrados a través de la obra de Forner contra la familia Iriarte.

\section{LOS GRAMÁTICOS. HISTORIA CHINESCA (1782)}

La lucha entre intelectuales alcanza un elevado tono con el enfrentamiento entre Juan Pablo Forner y la familia Iriarte ${ }^{50}$,

${ }^{50}$ Debido al fuerte carácter advenedizo de la familia Iriarte y su fulgurante ascenso (don Juan, por ejemplo, pasa en poco tiempo de preceptor de los hijos del duque de Alba y de Béjar a bibliotecario real, a traductor de la Secretaría de Estado y a socio numerario de la Real Academia y de la de Bellas Artes de San Fernando) suscitaba el odio de sus más inmediatos competidores. Por ejemplo, fue conocido el enfrentamiento entre el intelectual valenciano Gregorio Mayáns i Siscar con Juan de Iriarte por el progreso académico y cultural en la Corte. Ambos fueron bibliotecarios reales y ambos escribieron gramáticas latinas que aspiraban a ser implantadas como oficiales en toda España. Dicho duelo finalmente lo ganó Iriarte porque tenía más influencias y se condujo de mejor forma en el ambiente cortesano, además de lograr que su gramática triunfara en toda España, frente a la de Mayáns, que sólo se aplicó con recelo en las universidades de la Corona de Aragón. El polígrafo valenciano representaba al obsoleto y "elitista" erudito de provincias en el que "no llega a consumarse totalmente la transformación del humanista en el hombre de letras moderno" (Perdomo Batista 2011, p. 379), frente a Iriarte (al igual que Feijoo) que, aunque no plenamente como su sobrino, ya se acercaba al sociable y refinado buen conversador y divulgador "hombre de letras" dieciochesco. 
especialmente con el más literato de la familia, Tomás ${ }^{51}$, quien escribió el citado Los literatos en Cuaresma por influencia de Los eruditos a la violeta, de su buen amigo José de Cadalso ${ }^{52}$. Esta obra, que constituye una incisiva sátira contra el mundo cultural y educativo de la última mitad del siglo XVIII, nos interesa especialmente porque en su último sermón (son seis sermones "laicos" dedicados a asuntos de erudición, que se distribuyen en cada domingo de Cuaresma ${ }^{53}$ ), trata el tema de la educación, dentro del que se encuentra la enseñanza de la gramática, donde aprovecha para atacar los "cuadernillos" ("tres, cuatro, cinco o más libros menores", Iriarte 2010, pos. 1399, de 2142) que siguen la refundición del Arte de Nebrija del jesuita Juan Luis de la Cerda, un "defectuoso sistema de un oscurísimo gramático" (pos. 1464, de 2142), poco didáctico por su confusión y prolijidad ya que, entre otros fallos, "da dos diversas definiciones de una misma cosa y de otras muy esenciales ninguna” (pos. 1400,

${ }^{51}$ Resulta interesante apreciar que tres de las obras de Forner, además publicadas en el mismo año de 1782 (El asno erudito, Los gramáticos. Historia chinesca y las Exequias...) arremeten tanto directa como indirectamente contra los Iriarte, especialmente contra Tomás. Se ha llegado a "sugerir la existencia de una enfermedad psicológica — una psicosis por envidia a los triunfadores". François López, en cambio, dio razones familiares, intelectuales e ideológicas para tal enfrentamiento (véase E. Martínez Mata y J. Pérez Magallón en su ed. de IrIARTE 2010, pos. 143, de 2142).

52 Según nos dice R. Merrit Cox (1972, p. 23), Los eruditos a la violeta (The superficial erudites) fue "a very sharp, incisive literary satire which influenced Iriarte a year later (1773) to write Los literatos en cuaresma (Writers in Lent)". Además, continúa Merrit, ambos escritores durante la etapa de la década de 1770 fueron "very close friends", ya que coincidían en La Fonda de San Sebastián, "where one of the most important tertulias met". Precisamente las tertulias funcionaban como "a kind of editorial", y en particular, en ésta, Cadalso e Iriarte, con otros más, "recited or read selections from their published and unpublished works".

${ }^{53}$ Un tal don Bonifacio "que reúne regularmente una tertulia en su mansión propone que durante los seis domingos de cuaresma se lleven a cabo seis sermones laicos dedicados a seis ámbitos distintos —el papel de la murmuración contra las novedades y su influencia en la modernización de las letras, la educación de los niños, el teatro, el arte poética, la crítica y las relaciones entre sexos-y pronunciados por seis individuos de los que frecuentan la tertulia, aunque asumiendo cada uno de ellos la personalidad y vestuario de seis destacados literatos de la historia universal: Teofrasto, Cicerón, Cervantes, Boileau, Pope y Tasso". Estas tertulias responden al espíritu de la época que desarrolló fundamentalmente las Sociedades patrióticas de amigos del país o academias como la de Azcoitia (E. Martínez Mata y J. Pérez Magallón en su ed. de IrIARTe 2010, pos. 162-172, de 2142). 
de 2142). Precisamente, por eso mismo es necesario que se proponga una nueva gramática de "algún hombre que, no habiendo dejado los escritos de los buenos autores latinos después de dar notorias pruebas de saber con perfección este idioma...", escribiese un "método" que se "contuviese en poco más de trescientas páginas" y que no "necesite de explicaciones de otros libros sueltos y sin omitir, además de las observaciones gramaticales, aquellas que enseñan las recónditas propiedades y delicadezas de la lengua que aprende" (pos. 1408, de 2142). Tomás de Iriarte está señalando a su tío Juan como "un erudito de esta nación", que "ha desempeñado, en efecto, tan ardua tarea y provechosa tarea", cuyo manual, como "piedra de toque para conocer los quilates del talento de algunos sujetos", preservará el latín de la decadencia de la enseñanza impartida por "maestros ignorantes" que "sería trabajo para ellos" y una afrenta "humillarse a estudiar un nuevo arte" (pos. 1418, de 2142), puesto que se empecinan en seguir la didáctica de "mayoristas" 54 y no optan por un método de "arreglados y sucintos... preceptos", con los que "en lengua castellana y en metro perceptible supo allanar las escabrosidades antiguas para que pudiese un joven adquirir en algunos meses la doctrina que muchos de ellos no han alcanzado en tantos años". De ese modo, Iriarte ve a su tío como el "hombre de letras" dieciochesco, "el nuevo intelectual convencido de su discurso ideológico" (pos. 198, de 2142) y a sus "ignorantes maestros" detractores como "los sesudos envidiosos" a los que el "hombre de letras" debe combatir.

Juan Pablo Forner, en su obra maestra Exequias de la lengua castellana. Una sátira menipea (1782), opina paradójicamente igual que Tomás de Iriarte acerca de los maestros que, siguiendo el método de Juan Luis de la Cerda y los "manualillos" que lo explican, "en vez de amaestrar a la juventud a hablar la lengua patria con propiedad, pureza y elegancia, la hacen hablar un latín bárbaro y pedantesco", por lo que "enseñan las doctrinas en un latín bárbaro" (2000, p. 191). Posteriormente, en su Gramáticos. Historia chinesca, Forner identificará a estos maestros de "latín bárbaro y pedantesco" con Juan de Iriarte, de modo que, en el fondo, plantea una réplica contra el elogio que Tomás

${ }^{54}$ En el siglo xviII, según el método pedagógico de los colegios de la Compañía de Jesús, el aprendizaje del latín se dividía en cinco años de menor a mayor dificultad: mínimos, medianos y mayores. Los mayoristas, por lo tanto, eran aquellos que estudiaban Mayores, que correspondía especialmente a los niveles más dificultosos de la oración latina. 
hiciera de su tío Juan, a quien veía como "salvador de la lengua latina". De una forma harto irónica, como veremos, Forner describe a Juan de Iriarte bajo las mismas cualidades que achacaba su sobrino Tomás a los detractores de su tío, casi como un "maestro ignorante", de los seguidores del "oscurísimo" J.L. de la Cerda. Por consiguiente, se demuestra que en la sátira dieciochesca entre "hombres de letras", aunque muchas veces perseguían los mismos objetivos, acababan predominando las enemistades personales. Forner, en sus obras satíricas, adoptaba un "carácter revanchista" (Uzcanga 2001, p. 446) que hace que prevalezca constantemente su faceta destructiva (pars destruens), sin que exista prácticamente la constructiva (pars construens). De este modo, Los gramáticos. Historia chinesca es una diatriba o una invectiva agresiva y destructiva contra la familia Iriarte, en especial contra Juan y Tomás de Iriarte ${ }^{55}$ (otra obra que, a modo de diatriba, complementa a ésta contra la familia Iriarte, especialmente contra Tomás, es El asno erudito, 1782).

En la denuncia que Forner hace de los dos Iriarte, nos interesa especialmente el ataque contra Juan de Iriarte que, aunque breve, es sumamente significativo, pues, como dijimos, para Forner es el modelo perfecto de gramático pedante y afrancesado. Iriarte estudió con los jesuitas en el colegio de San Luis el Grande en París y continuó su formación en Ruán. Posteriormente fue preceptor de don Joaquín Zúñiga, conde de Belalcázar y futuro duque de Béjar, de don Fernando de Silva Álvarez de Toledo, marqués de Coria y posterior duque de Alba, y también del infante don Manuel de Portugal. La nobleza, impulsada por la moda galicista que introdujo la nueva dinastía borbónica, busca los servicios de preceptores que se habían formado en el país vecino, como Juan de Iriarte, sin examinar de antemano la calidad de la instrucción que ofrecían.

Para ridiculizar a estos enseñantes ante una nobleza tan convencida de su calidad de enseñanza, Forner pretende demostrar

55 En una parte de su estudio, Pérez Lasheras (1994, pp. 188-189), basándose en definiciones de la sátira del Diccionario de Autoridades, de la Real Academia de la Lengua y en las apreciaciones que sobre ellas da Woodhouse, llega a la conclusión de que la sátira tendría dos grandes modalidades: por un lado, "la que se centra en el ataque personal" y, por otro, la sátira que "critica los vicios del hombre en general, sin hacer mención explícita de casos o personas concretas”. Según esto, la sátira de Forner contra los Iriarte se incluiría en el primer tipo y coincidiría con la modalidad satírica de diatriba o invectiva. 
en el capítulo IV de esta obra el corrompido gusto del humanista canario, de un lado por sus críticas al eminente helenista y latinista Manuel Marti ${ }^{56}$ y, de otro lado, por su método de enseñar latinidad, en el que utilizaba refranes españoles ${ }^{57}$ traducidos al latín, lo que era propio de los métodos barrocos de los Taranillas, Zancas-Largas y Supinos. Nosotros nos fijaremos en su método con la ayuda del siguiente pasaje donde Forner compara a Iriarte con el dómine Zancas-Largas, de Isla:

Qualquier mayorista — como, sin duda lo era Juan de Iriarte, ya que había estudiado con los jesuitas en el Colegio San Luis el Grande de París-, bien haya estudiado con el dómine ZancasLargas, sabe y le consta, por poco que reflexione en lo que le hacen aprender, que los adagios o refranes castellanos no pueden traducirse literalmente en latín so pena de cometer un barbarismo que le exponga al látigo o a la férula. Confirmaráse más en esta verdad, si llega a leer por casualidad la siguiente cláusula entresacada del tomo segundo de las Obras sueltas del ya citado don Juan de Yriarte: la traducción demasiado literal trae consigo varios inconvenientes, ya el de pervertir el sentido del texto, ya el de poner la sentencia más obscura de lo que estaba en el original o, a lo menos, dexarla tan latina o griega, después de traducida, como antes, o ya, en fin, sobre quitar toda la fuerza y gracia de los conceptos ocasiona expresiones estrañas y disonantes o no significativas. Y bien ¿̇observó en sí el dictador la ley con que juzgaba a otros tan rígidamente? Nada menos. Los déspotas no están sugetos a la ley que imponen a los súbditos. Y, con efecto, el señor don Juan, o por mostrar que los grandes hombres no deben atarse a los decretos del común o por el gustazo de contradecirse, tradujo literalísimamente en latín una multitud de nuestros refranes, cuyos modismos, locuciones y alusiones ceñidas en gran parte a los estilos y usos de la nación, tienen tanto que ver con la lengua de Virgilio, como un huebo con una castaña $(1970$, p. 46).

56 El ataque de Iriarte a Martí, independientemente de otras causas, estaría relacionado con la enemistad que el canario sentía hacía su principal competidor intelectual, Gregorio Mayáns, del que Martí fue maestro.

${ }^{57}$ Juan de Iriarte se basa sin duda en gramáticos anteriores que utilizaron los refranes como medio para enseñar la lengua latina, como Jerónimo Caro y Cejudo en Refranes y modo de hablar castellanos con latinos, que les corresponden juntamente con la glosa y explicación de la que tienen necesidad de ella, Julián Izquierdo, Madrid, 1675. 
A cada puerco le viene su San Martín.

Stat sua cuique sui Martini tempore caedes.

A gallego pedidor, castellano tenedor.

Castellane tenax, Gallaeco obsiste petaci.

A carnero castrado no le tientes el rabo.

Ne tua vervecis pertentet dextera caudam.

Achaques al viernes por no ayunarle.

Quid Veneris lucem, vitans jejunia, culpas?

Más caga un buey que cien golondrinos.

Plus decies dena vel hirundine bos cacat unus.

Quando la barba de tu vecino veas pelar, echa la tuya a remojar. Vicinam ut radi dabitur tibi cernere barbam tunc propera linphis tingere, amice, tuam

(pp. 45-46).

Para causar mayor efectismo en su "sátira gramatical", Forner se apoya en elementos carnavalescos, como la identificación del ilustrado tinerfeño con el dómine Zancas-Largas, de Isla, o el contenido cómico y escatológico de alguno de los refranes que expone. La realidad de la figura de Juan de Iriarte se mezcla con la ficción novelesca de Zancas-Largas. Sin duda, el odio de Forner hacia Iriarte es lo que le empuja a introducir esta comparación caricaturesca que desvía la seriedad de la diatriba formal dieciochesca en una dirección paródica ${ }^{58}$, y se acrecienta con la calificación que da a don Juan de "déspota" que aplicaba un mal aprendizaje del latín, abiertamente opuesta a la que le daba su sobrino Tomás de "erudito", con "quilates de talento", "después de dar notorias pruebas de saber con perfección este idioma”.

Para concluir, si Vera de la Ventosa arremetió contra el modelo gramatical ilustrado francés a través de la gramática de Iriarte,

58 M.C. Carbonell 1992, p. 45, señala que precisamente en los aspectos negativos de la crítica literaria, provocados por la envidia, la venganza, el odio, etc., Iriarte, en sus Literatos en Cuaresma, "había alertado sobre los peligros que acechaban a la crítica", y lo hizo "con palabras que sin duda hubiera suscrito Forner, salvo en uno significativo: el matiz despectivo con que el fabulista alude a la sátira...”. En efecto, en esto último Iriarte defendía una sátira que apelara a "las buenas intenciones" (UzcANGA 2001, p. 444), siguiendo el concepto de true satire inglés, en tanto que Forner se convirtió en el "satírico impenitente" que si ve necesario acrecentar el aspecto ridículo del satirizado lo hará por el bien de mejorar la calidad satírica. En ese aspecto se acerca a la sátira carnavalesca de un Quevedo, "como si la sombra del Quevedo socarrón y burlesco fuera todavía muy larga y el alarde de ingenio una tentación demasiado grande" (p. 446). 
Forner lo hizo contra su propia figura de "pedante" trasnochado a través de sus versos y refranes latinos macarrónicos.

\section{Conclusiones}

Aunque la "sátira gramatical" ha ido variando en los diferentes tipos de preceptores de gramática latina, objeto de su zaherimiento, entre la Antigüedad y el siglo XviII (el gramático romano, el gramático escolástico, el pedante humanista, el gramático barroquizante o el pedante ilustrado), la esencia de su crítica siempre ha sido la misma, la denuncia de la afectación, el latín bárbaro y el fárrago del método didáctico. Este tipo de sátira, por lo tanto, se configura como una sátira educativa poco convencional que se representa a través de un crisol de manifestaciones literarias donde se mezclan, entre otros, los rasgos propios de la lírica, la novela humanista, el ensayo, la novela picaresca o la comedia. Si bien esto se mantiene en el siglo XVIII, hemos de matizar que durante este periodo se dan dos giros relevantes de este tipo de sátira: una continuista con la tradición que mantiene el aspecto caricaturesco del profesor de latín, pero en lugar de conservar únicamente la pars destruens, genera una pars construens que busca la regeneración de la enseñanza de la latinidad a través de la carnavalización y los ataques didáctico-morales. Si en siglos pasados sólo se enfocaban en el aspecto cómico de la figura del enseñante de latín (como en el caso de Espinel o Quevedo) o bien buscaban la crítica a una forma de enseñanza del latín determinada como el caso de los humanistas contra los escolásticos, en el siglo XVIII, un Isla o un Vegas y Quintano pretenden que la sátira gramatical trascienda la mera profesión de dómine y logre "metonímicamente" mostrar una enseñanza degenerada que requiere de pronta regeneración. Pero la riqueza de la sátira gramatical sobre el preceptor de latín del siglo xviıI no se queda ahí solamente, sino que también adquiere una vertiente cultural al reflejar y servir de "arma literaria" en las luchas intelectuales entre los hombres de letras del xvirI.

De esta manera, por un lado, el dómine, mal enseñante de latín, pone la semilla de un tipo social determinado que degrada a la sociedad: la enseñanza del latín barroco crea al predicador charlatán (Isla) o bien degrada la educación (Vegas y Quintano). 
La enseñanza del latín ilustrado crea al violeto de tipo político, afrancesado y petit-maître como Olavide (Vera de la Ventosa) o se entremezcla con la didáctica barroca (Forner) y da pie al erudito pedante, como Iriarte.

Por otro lado, sirve de herramienta para el zaherimiento entre diversos tipos sociales enemistados dentro de la sociedad española del xviII: el jesuita contra el fraile (Isla); el profesor ilustrado contra el jesuita (Vegas y Quintano); el fraile contra el "hombre de letras" ilustrado (Vera de la Ventosa); los eruditos contra los "hombres de letras" (Forner e Iriarte). En definitiva, en esta dinámica de todos contra todos, la sátira se emplea para purgar tipos sociales, partiendo de la crítica mordaz asentada sobre el pésimo enseñante de latinidad. En conclusión, la "sátira gramatical" trasciende las fronteras de la filología o historia de la educación para convertirse en un elemento de proyección de una gran y variada cantidad de matices sociales de un país en una determinada época.

\section{REFERENCIAS}

Aguilar Piñal, Francisco 1968. "La Real Academia Latina Matritense en los planes de la Ilustración”, Anales del Instituto de Estudios Madrileños, 3, pp. 183-217.

Aguilar Piñal, Francisco 1969. La Universidad de Sevilla en el siglo XVIII. Estudio sobre la primera reforma universitaria moderna, Universidad, Sevilla. (Anales de la Universidad Hispalense, 1).

Aguilar Piñal, Francisco 1988. "Entre la escuela y la universidad. La enseñanza secundaria en el siglo xvıı", Revista de Educación, Madrid, núm. extraordinario, pp. 227-243.

Aguilar Piñal, Francisco 2009. Reseña de "El siglo ilustrado. Vida de don Guindo..., ed. de M. Dubuis y M.I. Terán Elizondo”, Cuadernos Dieciochistas, 10, pp. 325-327.

Alieghero Manacorda, Mario 1987. Historia de la educación. T. 1: De la Antigüedad al 1500, Siglo XXI, México.

Álvarez Barrientos, J. 1999. "El violeto de Cadalso como bel esprit", en Ideas en sus paisajes. Homenaje al profesor Russell P. Sebold. Eds. G. Carnero, E. Rubio e I.J. López, Universidad, Alicante, pp. 43-62.

Álvarez BARRientos, JoAQuín 2006. Los hombres de letras en la España del siglo XVIII. Apóstoles y arribistas, Castalia, Madrid.

Bajtin, Mijail 1998. La cultura popular en la Edad Media y en el Renacimiento. El contexto de François Rabelais, $6^{a}$ ed., Alianza, Madrid.

Bartolomé Martínez, Bernabé 1993. "Las escuelas de gramática" [en el siglo XVII], en Historia de la educación en España y América. T. 2: La educación de la España moderna (siglos XVI-XVIII). Coord. B. Delgado Criado, S.M.Morata, Madrid, pp. 504-514, 812-821. 
Bergua Cavero, Jorge (ed.) 1997. Contra los profesores, de Sexto Empírico. Libros I-VI, Gredos, Madrid.

Cañigral Cortés, Luis de 1996. “"Ahí está Menckenio... que no me dejará mentir». Algunas fuentes latinas de Fray Gerundio de Campazas”, Castilla: Estudios de Literatura, 21, pp. 57-63.

Carbonell, María Cristina 1992. "Las exequias de la lengua castellana de Juan Pablo Forner, «Sátira Menipea», Anales de Literatura Española, 8, pp. 37-52.

Cervantes, Miguel de 1980. Coloquio de los perros, en Novelas ejemplares. Ed. Harry Sieber, Cátedra, Madrid.

Chem Sham, Jorge 1999. "Fray Gerundio de Campazas" o la corrupción del lenguaje. Sátira y escamoteo autorial, Universidad de Costa Rica, San José.

Cox, R. Merrit 1972. Tomás de Iriarte, Twayne, New York.

Cuyás y Torres, María Elisa de 1992. "La gramática latina de Juan de Iriarte”, Excerpta Philologica, 2, pp. 9-17.

DétTore, Ugo 2006. "Pedante [El]", en Diccionario literario Bompiani de obras y personajes de todos los tiempos y de todos los paises, Hora, Barcelona, t. 6, p. 6795.

Espino Martín, J. 2003. "Racionalismo e Ilustración en la enseñanza del latín: evolución de las gramáticas escolapias en la segunda mitad del siglo XviII", Cuadernos de Filología Clásica. Estudios Latinos, 23, 2, pp. 423-435.

EsPino Martín, Javier 2004. Evolución de la enseñanza gramatical jesuítica en el contexto socio-cultural español entre los siglos XVI y primera mitad del XVIII, tesis, Universidad Complutense de Madrid, http://www.eprints.ucm.es/tesis/ fll/ucm-t28425.pdf.

EsPino MARTín, J. 2010. "Enseñanza del latín e historia de las ideas: la revolución de Port Royal y su repercusión en Francia y España durante el siglo xvin", Minerva. Revista de Filología Clásica, 23, pp. 261-284.

EsPino MARTín, J. 2010a. "Los jesuitas frente al racionalismo del Brocense: la enseñanza del latín en la España de los siglos xviı y xviı", Calamus Renascens. Revista de Humanismo y Tradición Clásica, 11, pp. 61-87.

Espino Martín, J. 2012. Política y gramática en el siglo XVIII: Ilustrados contra jesuitas. Evolución de la enseñanza jesuítica del latín en el siglo XVIII español: la Corona de Castilla, Editorial Académica Española, Saarbrücken.

Espino Martín, J. 2013. “"Sátira gramatical» y emancipación: la figura del profesor de latín en la obra de Fernández de Lizardi”, Nova Tellus, 31, 1 , pp. 159-186.

EsPino MARTín, J. 2015. "Barroquismo carnavalesco o empirismo ilustrado en la enseñanza del latín en el siglo xviı: La Gramática y conducta del dómine Don Supino (1790) de Manuel de Vegas y Quintano", en Humanismo y pervivencia del mundo clásico. V. (Homenaje al profesor Juan Gil). Eds. J.M. Maestre Maestre, S.I. Ramos Maldonado y M.A. Díaz Gito, Instituto de Estudios Humanísticos-CSIC, Alcañiz-Madrid, pp. 2743-2761.

EsPino MARTín, Javier 2015a. "La enseñanza gramatical al servicio de la propaganda religiosa contrarreformista. La «retorización» de la gramática latina en el siglo Xviı", en Ianva Classicorvm. Temas y formas del Mundo Clásico. Eds. J. de la Villa Polo y P. Cañizares Ferriz, Sociedad Española de Estudios Clásicos, Madrid, t. 3, pp. 337-345.

Fernández, Luis 1952. "La biblioteca particular del P. Isla”, Humanidades, 4, pp. 128-141. 
Forner, Juan Pablo 1970 [1782]. Los gramáticos. Historia chinesca. Ed. J. Jurado, Espasa-Calpe, Madrid.

Forner, JuAn Pablo 2000 [1782]. Exequias de la lengua castellana. Sátira menipea, por el Licdo. Don Pablo Hipnocausto. Ed. J. Jurado, CSIC, Madrid.

García Jurado, Francisco y Pilar Hualde Pascual 2004. "La Academia (greco) latina matritense. Primera parte: su historia (1755-1849)", Minerva. Revista de Filología Clásica, 17, pp. 165-198.

García Jurado, Francisco y Pilar Hualde Pascual 2005. "La Academia (greco) latina matritense (1755-1849). Segunda parte. Actividad filológica y documentos", Minerva. Revista de Filología Clásica, 18, pp. 211-225.

García Jurado, Francisco y Javier Espino Martín 2009. El profesor de latín en la literatura española, Liceus (El Portal de Humanidades), http://www. liceus.com.

Gaudeau, Bernard 2010. Étude sur Fray Gerundio et sur son auteur: Le P. José Francisco de Isla, 1703-1781 (1890), Kessinger Legacy, Montana.

Gil Fernández, Luis 1980. "Gramáticos, humanistas, dómines”, El Basilisco, 9 , pp. 20-30.

GiL, Luis 1981. Panorama social del humanismo español (1500-1800), Alhambra, Madrid.

Haidt, Rebecca 2002. Seduction and sacrilege. Rhetorical power in "Fray Gerundio de Campazas", Brucknell University Press- Associated University Press, Lewisburg-London.

Iriarte, Tomás de 2010 [1773]. Los literatos en Cuaresma. Eds. Emilio Martínez Mata y Jesús Pérez Magallón, Clásicos Biblioteca Nueva-Biblioteca Digital, versión Kindle.

Isla, José Francisco de 1995 [1758]. Historia del famoso predicador Fray Gerundio de Campazas alias Zotes. Ed. Enrique Rodríguez Cepeda, Cátedra, Madrid.

López de Santamaría, Javier 1994. "La consideración social de los maestros en Roma”, en Actas del VIII Congreso Español de Estudios Clásicos, Eds. Clásicas, Madrid, 1994, t. 3, pp. 223-230.

Martínez Fernández, José EnRIQue 2000. "Retrato y nombre propio (huellas literarias y carnavalescas en los retratos del Fray Gerundio de Campazas)", en El retrato literario. Tempestades y naufragios. Escritura y reelaboración. Actas del XII Simposio de la Sociedad española de Literatura General y Comparada. Eds. M.A. Márquez, A. Ramírez de Verger y P. Zambrano, Universidad de Huelva, Huelva, pp. 285-291.

Negrín Fajardo, Olegario (coord.) 2009. Historia de la educación española, UNED, Madrid.

Ozuna Castañeda, Mariana 2004. "El siglo ilustrado. Vida de don Guindo Cerezo. Aproximación a un género literario del siglo xvinı", Boletín del Instituto de Investigaciones Bibliográficas, 9, 1/2, pp. 79-98.

Palmer, Joe L. 1971. "Elements of social satire in Padre Isla's Fray Gerundio de Campazas", Kentucky Romance Quarterly, 18, pp. 195-205.

Palmer, Joe L. 1973. "La juventud triunfante and the origins of Padre Isla's satire”, Hispania, 56, pp. 75-80.

Perdomo Batista, Miguel A. 2010-11. "La ascensión de los Iriarte. A propósito de la relación entre políticos y literatos en la España del absolutismo borbónico", Philologica Canariensia, 16/17, pp. 193-220. 
Perdomo Batista, Miguel A. 2011. "El enfrentamiento de Mayans y los Iriarte a propósito de gramáticas latinas”, Cuadernos de Filología Clásica. Estudios Latinos, 31, 2, pp. 355-388.

Pérez Lasheras, Antonio 1994. Fustigat Mores. Hacia el concepto de sátira en el siglo XVII, Universidad, Zaragoza.

Pérez Picón, Francisco 1983. Un colegio ejemplar de letras humanas en Villagarcía de Campos, Sal Terrae, Santander.

Torres-Alcalá, Antonio 1984. "Verbi gratia”: los escritores macarrónicos de Espa$\tilde{n} a$, J. Porrúa Turanzas, Madrid.

Vegas y Quintano, Manuel de 1790. Gramática y conducta del dómine Don Supino, discípulo del dómine Mazorrales, y la que expresa su crítico preguntador, Imprenta de D. Joseph Antonio Ibarrola, Alcalá de Henares.

Vera de la Ventosa, Justo 2010 [1777]. El siglo Ilustrado, vida de Don Guindo de Cerezo. Eds. Michel Dubuis e Isabel Terán, Porrúa, México.

Viñao, Antonio 2009. "La educación cívica o del ciudadano en la ilustración española: entre la tradición republicana y el liberalismo emergente", Res Publica, 22, pp. 279-300.

Uzcanga Meinecke, Francisco 2001. "Ideas de la sátira en el siglo xviII: hacia una nueva función en el marco de la ideología ilustrada”, Revista de Literatura, 63, 126, pp. 425-459.

Zavala, IrIs M. 1987. Lecturas y lectores del discurso narrativo dieciochesco, Rodopi, Amsterdam. 